\title{
Soybean Fertilized by P-Phases from Bagasse-Based Materials: P-Extraction Procedures, Diffusive Gradients in Thin Films (DGT), and X-ray Diffraction Analysis (XRD)
}

\author{
Hannes Herzel ${ }^{1, *,+} \oplus$, Vitalij Dombinov ${ }^{2, *,+} \oplus$, Christian Vogel ${ }^{1}\left(\mathbb{D}\right.$, Sabine Willbold ${ }^{3}(\mathbb{C}$, \\ Gabriel Vettorazzi Levandowski ${ }^{4}$ (D), Martin Meiller ${ }^{5}$, Felix Müller ${ }^{6}$, Joachim Werner Zang ${ }^{7}$ (D), \\ Warde Antonieta da Fonseca-Zang ${ }^{7} \mathbb{D}$, Nicolai David Jablonowski ${ }^{2} \mathbb{D}$, Silvia Diane Schrey ${ }^{2}$ and \\ Christian Adam ${ }^{1}$ (D) \\ 1 Bundesanstalt für Materialforschung und-prüfung (BAM), Division 4.4 Thermochemical Residues Treatment \\ and Resource Recovery, Unter den Eichen 87, 12205 Berlin, Germany; christian.vogel@bam.de (C.V.); \\ christian.adam@bam.de (C.A.) \\ 2 Institute of Bio- and Geosciences, IBG-2: Plant Sciences, Forschungszentrum Jülich GmbH, \\ 52428 Jülich, Germany; n.d.jablonowski@fz-juelich.de (N.D.J.); s.schrey@fz-juelich.de (S.D.S.) \\ 3 Central Institute for Engineering, Electronics and Analytics, Analytics (ZEA-3), Forschungszentrum Jülich \\ GmbH, 52425 Jülich, Germany; s.willbold@fz-juelich.de \\ 4 Escola de Agronomia, Universidade Federal de Goiás (UFG), CEP 74.690-900 Goiânia, Brazil; \\ gabriel.vl@basevis.com.br \\ 5 Fraunhofer UMSICHT, Energy Technology, 92237 Sulzbach-Rosenberg, Germany; \\ martin.meiller@umsicht.fraunhofer.de \\ 6 TU Clausthal (CUTEC), 38678 Clausthal-Zellerfeld, Germany; felix.mueller@cutec.de \\ 7 Instituto Federal de Goiás (IFG), CEP 74.690-900 Goiânia, Brazil; dr.zang2000@gmail.com (J.W.Z.); \\ warde@quimica-industrial.com (W.A.d.F.-Z.) \\ * Correspondence: herzelhannes@gmail.com (H.H.); v.dombinov@fz-juelich.de (V.D.) \\ + Both authors contributed equally.
}

Received: 1 May 2020; Accepted: 20 June 2020; Published: 23 June 2020

\begin{abstract}
The Brazilian sugarcane industry produced around 173 million tons (Mt) of bagasse in 2018. Bagasse is a by-product of juice extraction for ethanol and sugar production and is combusted in order to generate power, producing up to $10 \mathrm{Mt}$ of ash per year. This ash contains various concentrations of plant nutrients, which allow the ash to be used as a crop fertilizer. However, the concentration and extractability of phosphorus $(\mathrm{P})$, an essential plant nutrient, are low in bagasse ash. To increase the $\mathrm{P}$ content, we co-gasified and co-combusted bagasse with P-rich chicken manure. The resulting ash was thermochemically post-treated with alkali additives $\left(\mathrm{Na}_{2} \mathrm{SO}_{4}\right.$ and $\left.\mathrm{K}_{2} \mathrm{SO}_{4}\right)$ to increase the availability of $\mathrm{P}$ to plants. We aimed to: (i) investigate the effect of thermochemical post-treatment of co-gasification residue and co-combustion ash on $\mathrm{P}$ availability to soybeans, (ii) explore the potential of chemical extraction methods (citric acid, neutral ammonium citrate, formic acid, and Mehlich-I) and diffusive gradients in thin films (DGT) to predict the availability of $P$ to soybeans, and (iii) identify the responsible P-phases using X-ray diffraction. We evaluated $\mathrm{P}$ availability to soybeans growing in Brazilian Oxisol soil in two independent greenhouse pot experiments. The positive effect of thermochemical treatment on $\mathrm{P}$ availability from gasification residue was confirmed through the observation of increased P uptake and biomass in soybean plants. These findings were confirmed by chemical extraction methods and DGT. The gasification residue contained whitlockite as its main P-bearing phase. Thermochemical post-treatment converted whitlockite into highly soluble $\mathrm{CaNaPO}_{4}$. In contrast, co-combustion ash already contained highly soluble $\mathrm{Ca}(\mathrm{Na}, \mathrm{K}) \mathrm{PO}_{4}$ as its main P-bearing phase, making thermochemical post-treatment unnecessary for increasing $\mathrm{P}$ availability. In conclusion, increased extractability and availability of $\mathrm{P}$ for soybeans were closely connected to the formation
\end{abstract}


of calcium alkali phosphate. Our findings indicate that this combined methodology allows for the prediction of P-fertilization effects of ash.

Keywords: sugarcane bagasse/chicken manure ash; thermochemical treatments; extraction analyses; XRD; NMR; DGT; P plant availability to soybeans; greenhouse pot experiments

\section{Introduction}

In 2018, the Brazilian sugarcane industry produced around 173 million tons (Mt) of bagasse. Bagasse, the fibrous plant material remaining after sugarcane juice extraction [1], is usually directly combusted to generate the energy required in sugar mills [2], with any excess energy supplied to the local power grid [2,3]. Bagasse combustion produces up to $10 \mathrm{Mt}$ of ash annually (calculation based on $[1,2,4])$.

The ash is used as a liming agent or fertilizer for various crops [5-8], as it is alkaline and contains mineral nutrients, including phosphorus $(\mathrm{P})$ and potassium $(\mathrm{K})$, at various concentrations. Plant availability of $\mathrm{K}$ from biomass ash was reported to be comparable to that from potassium chloride (KCl) [9,10], but highly dependent on soil properties, including clay content and acidity [9]. In contrast, $\mathrm{P}$ availability depends on multiple factors, such as type of combusted biomass, co-combustion with other fuel sources, combustion technology, operational conditions of the combustion process, soil acidity and plant species [11-14]. Ferreira et al. [5] reported increased concentration and extractability of $P$ in bagasse ash after co-combustion with nutrient-rich bovine sub-products, such as fat, bone and blood.

These findings motivated us to ask whether $\mathrm{P}$ concentration and availability from bagasse ash could be increased by co-combusting and co-gasifying the bagasse with chicken manure, an organic fertilizer [15] abundant in Brazil [4]. Manure is applied to soils as a disposal practice, which poses environmental risks due to the high solubility of $\mathrm{P}$ in the animal waste [16]. Solubility of $\mathrm{P}$ from nutrient-rich biomass in water is known to decrease greatly after thermal processing [17-19]. Thermochemical treatment of the resulting residue and ash from co-gasification and co-combustion has been found to increase $\mathrm{P}$ availability in a process originally developed for the treatment of sewage sludge ash [20-22]. This thermochemical process was performed using sodium and potassium additives (e.g., $\mathrm{Na}_{2} \mathrm{SO}_{4}$ and $\mathrm{K}_{2} \mathrm{SO}_{4}$ ) at temperatures between $900-1000{ }^{\circ} \mathrm{C}$ [23].

Various methods have been published for extracting $\mathrm{P}$ from biomass ash and products from thermochemical treatments. These extraction methods have been shown to predict the plant-available $P[19,24]$. In particular, extractions of $P$ from ash using neutral ammonium citrate (NAC), citric acid (CA), or formic acid (FA) have been shown to correlate with fertilizer performance [19]. To the best of our knowledge, bagasse-based fertilizers have not previously been tested with these extraction methods.

Extraction of $\mathrm{P}$ with Mehlich-I solution is a standard method to measure plant-available $\mathrm{P}$ in Brazilian Oxisol soil [25]. In the current study, this method was compared with the novel diffusive gradients in thin films (DGT) technique to predict $P$ availability for plants from co-gasification residue, co-combustion ash and their respective thermochemical products in Oxisol. The DGT technique was reported to predict $\mathrm{P}$ availability for plants from organic matter and conventional fertilizers [17,26-28] as well as from sewage sludge-based fertilizers [29,30]. For DGT, fertilizer is mixed with soil and incubated for several days prior to analysis of the DGT binding layer, which mimics root absorption of P. Therefore, DGT analysis correlates better with plant $\mathrm{P}$ uptake compared to common standard extraction tests used with conventional and recycling P-fertilizers $[29,30]$.

The availability of P-fertilizers is connected to their crystalline P-phase composition [24,31]. Crystalline P-phases are usually determined by X-ray diffraction analysis (XRD). Such XRD data from mono-thermal treatment of bagasse or chicken manure are available from previous studies [18,32-36]. The P-phases in chicken manure ash seem to vary depending on combustion process conditions, and can commonly consist of apatite, various pyrophosphates and $\mathrm{Ca}_{2} \mathrm{NaKPO}_{4}$ with $\mathrm{KMg}\left(\mathrm{PO}_{3}\right)_{3}$, 
$\mathrm{CaKPO}_{4}$ and whitlockite appearing rarely [18,32-34]. In bagasse ash, only calcium phosphates were reported [35,36]. All these P-phases can be converted into calcium alkali phosphates such as $\mathrm{CaNaPO}_{4}$, $\mathrm{CaKPO}_{4}$, or $\mathrm{Ca}_{13} \mathrm{Mg}_{5} \mathrm{Na}_{18}\left(\mathrm{PO}_{4}\right)_{18}$ by thermochemical treatment [21,23,37]. Calcium alkali phosphates are described as poorly water-soluble but highly plant-available [21,22].

In this study, bagasse was either co-gasified or co-combusted with chicken manure to increase the concentration of $\mathrm{P}$ in the products. Subsequently, the products were thermochemically treated to determine whether this process increased plant-available P. All products were assayed for P-fertilizing potential using soybeans (Glycine $\max$ (L.) Merr.) under controlled greenhouse conditions. Soybean was used as the model crop because it is one of most cultivated crops in Brazil [4,38]. Furthermore, soybeans are frequently cultivated between sugarcane rotations to restore soil fertility via symbiotic nitrogen fixation $[39,40]$.

The objectives of this study were to: (i) investigate the effect of thermochemical post-treatment of co-gasification residue and co-combustion ash on $\mathrm{P}$ availability to soybeans, (ii) explore the potential of various chemical extraction methods (CA, NAC, FA, and Mehlich-I) and DGT to predict the availability of $\mathrm{P}$ to soybeans, as well as (iii) identify P-phases with XRD with different availabilities of $\mathrm{P}$. We hypothesized that thermochemical post-treatments of co-gasification residue and co-gasification ash increase the availability of $\mathrm{P}$ for soybeans due to the conversion of less plant-available $\mathrm{P}$ from crystalline P-phases such as whitlockite into more available P from calcium alkali phosphates.

\section{Materials and Methods}

\subsection{P-Fertilizer Preparation}

In the present study, the fertilizers were all prepared using previously pelletized bagasse (Usina Nova Gália Ltda., Paraúna, Goiás, Brazil) and chicken manure (Jürgen Abeler GmbH and Co. KG, Nordwalde, Germany). In a first step, mixtures of bagasse pellets and chicken manure pellets were thermally converted by co-gasification or co-combustion (Figure 1). Based on Herzel et al. [23], ash and residue from both co-combustion and co-gasification were thermochemically post-treated in order to transform the existing P-phases into highly plant-available calcium alkali phosphates.

The co-combustion treatment was carried out in a grate furnace (HDG Compact 100, HDG Bavaria $\mathrm{GmbH}$, Massing, Germany) with $100 \mathrm{~kW}$ thermal output. The retention time on the grate was around 45 minutes (min.) and the temperature profile in the fire bed spanned from 400 up to $800{ }^{\circ} \mathrm{C}$ under oxidizing conditions $(\lambda=2.2)$. This co-combustion ash, named ASH, was produced from mixtures of bagasse pellets and chicken manure pellets at a ratio of $60 / 40 \mathrm{wt} . \%$.

The co-gasification treatment was carried out in a circulating fluidized bed gasifier (ArtFuel-Gasifier, T \& M Engineering, Bad Frankenhausen, Germany, modified by TU CUTEC, Clausthal-Zellerfeld, Germany) at $827^{\circ} \mathrm{C}$ under reducing conditions $(\lambda=0.4)$ [41]. Due to technical reasons, the fraction of chicken manure was decreased substantially relative to that used in the combustion treatment. It was observed in pre-investigations that during the gasification process there is an accumulation of $\mathrm{P}$ in the main gasification residue, whereas a bottom ash of low P-content separates out. Consequently, the co-gasification residue is P-enriched [41,42]. In order to produce comparable total P-contents from combustion ash and gasification residue, a mixture of $85 \mathrm{wt} . \%$ bagasse pellets and $15 \mathrm{wt} . \%$ chicken manure pellets was gasified. The resulting co-gasification residue is named GR.

GR and ASH were then thermochemically post-treated sequentially (Figure 1). The ASH sample had to be mixed with $23 \mathrm{wt}$.\% milled chicken manure as a carbon source to achieve the reducing atmosphere required for the thermochemical process [23,37]. No carbon source was added for GR as it contained $36 \mathrm{wt} . \%$ loss on ignition (LOI) (Table 1), which is characteristic for gasification residues [43]. 


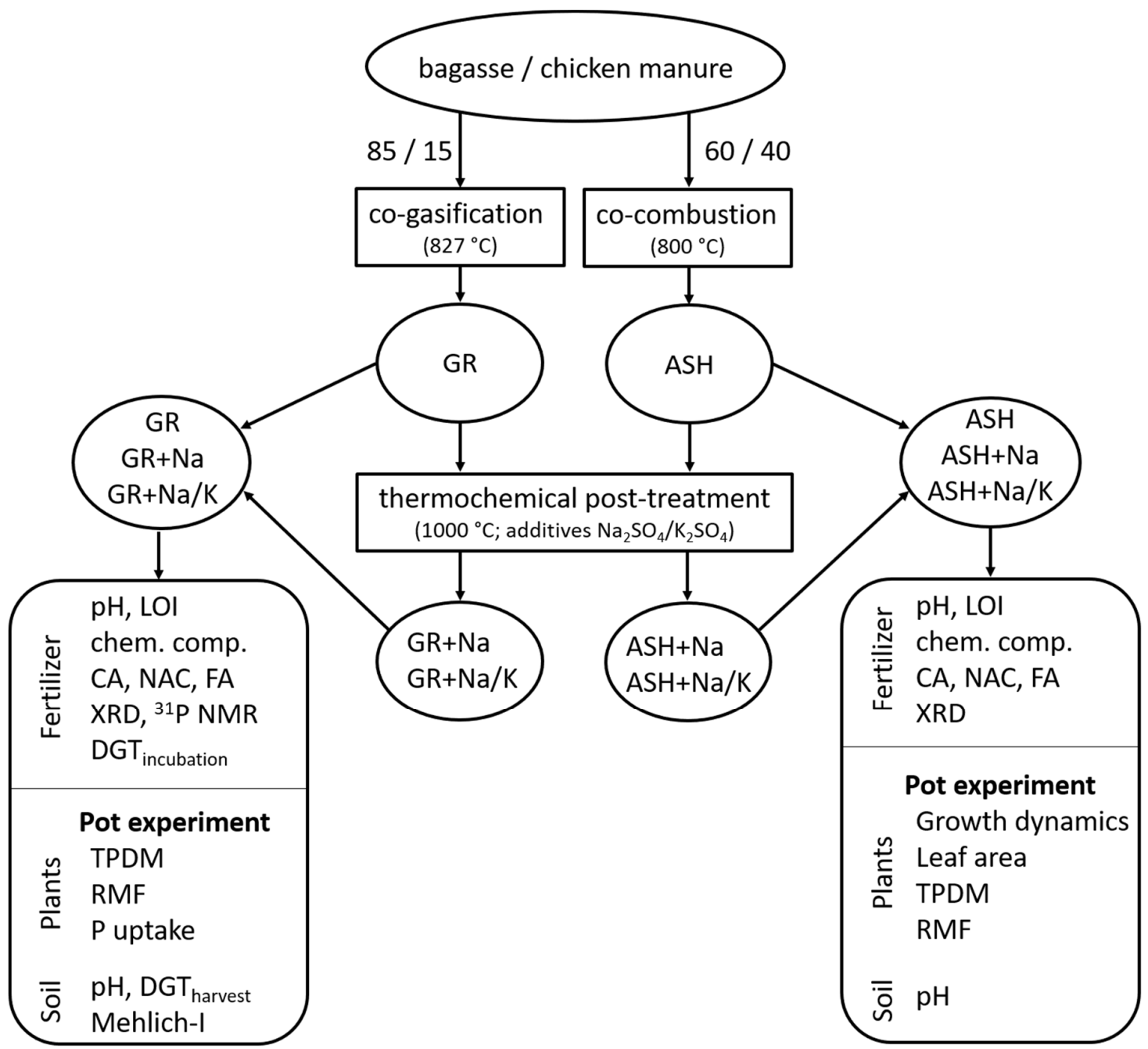

Figure 1. Flowchart for experimental setup. Bagasse was co-gasified and co-combusted with chicken manure in weight ratios of 85:15 and 60:40, respectively. Gasification residue (GR) and ash (ASH) were thermochemically treated with $\mathrm{Na}_{2} \mathrm{SO}_{4}(\mathrm{GR}+\mathrm{Na}, \mathrm{ASH}+\mathrm{Na})$ and $\mathrm{Na}_{2} \mathrm{SO}_{4} / \mathrm{K}_{2} \mathrm{SO}_{4}(\mathrm{GR}+\mathrm{Na} / \mathrm{K}$, $\mathrm{ASH}+\mathrm{Na} / \mathrm{K}$ ) at $1000^{\circ} \mathrm{C}$ for $30 \mathrm{~min}$. Chemical compositions, $\mathrm{pH}$ levels, loss of ignition (LOI), extractions in citric acid (CA), formic acid (FA), neutral ammonium citrate (NAC), as well as crystalline phases identified by $\mathrm{X}$-ray diffraction (XRD) were measured in all materials. Organic phosphorus (P)-species were analyzed in GR, GR+Na, and GR+Na/K by liquid ${ }^{31} \mathrm{P}$ nuclear magnetic resonance (NMR). GR, $\mathrm{GR}+\mathrm{Na}$, and $\mathrm{GR}+\mathrm{Na} / \mathrm{K}$ were mixed and incubated with Oxisol soil to apply diffusive gradients in

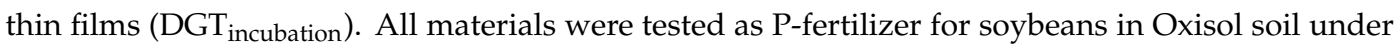
greenhouse conditions. Biomasses of GR, GR+Na, and $\mathrm{GR}+\mathrm{Na} / \mathrm{K}$ fertilized soybeans were analyzed for total plant dry matter (TPDM) from shoot and root organs, biomass partitioning to the roots expressed as root mass fraction $(\mathrm{RMF})$ and $\mathrm{P}$ uptake $\left(\Delta \mathrm{P}\right.$ uptake $(\mathrm{mmol})=\mathrm{P}_{\text {final harvest }}(\mathrm{mmol})-\mathrm{P}_{\text {fertilization beginning }}$ (mmol)). Extractability of $\mathrm{P}$ from the soil was measured by Mehlich-I extraction and DGT $\mathrm{T}_{\text {harvest }}$. Leaf areas of $\mathrm{ASH}, \mathrm{ASH}+\mathrm{Na}$, and $\mathrm{ASH}+\mathrm{Na} / \mathrm{K}$ fertilized soybeans were estimated with "ScreenHouse" platform over the growth period. True leaf areas, TPDM, and RMF were measured after the harvest. The $\mathrm{pH}$ levels were measured in all Oxisol soils. 
Table 1. $\mathrm{pH}(0.01 \mathrm{M} \mathrm{CaCl} 2)$, LOI (loss on ignition) at $550{ }^{\circ} \mathrm{C}$ and chemical composition for applied P-fertilizers displayed as mean value with standard deviation $(n=2)$ in wt. $\%$. Gasification residue (GR); ash (ASH).

\begin{tabular}{ccccccc}
\hline Fertilizer & GR & GR+Na & GR+Na/K & ASH & ASH+Na & ASH+Na/K \\
\hline $\mathrm{pH}$ & 11.6 & 10.5 & 10.6 & 12.7 & 9.5 & 9.3 \\
LOI $\left(550^{\circ} \mathrm{C}\right)$ & 36.0 & 8.0 & 8.1 & 2.8 & 0 & 0 \\
\hline \multicolumn{7}{c}{ Chemical Compositions } \\
\hline $\mathrm{Al}$ & $2.3 \pm 0.1$ & $2.5 \pm<0.1$ & $2.2 \pm 0.1$ & $1.6 \pm<0.1$ & $1.3 \pm<0.1$ & $1.2 \pm<0.1$ \\
$\mathrm{Ca}$ & $8.8 \pm 0.3$ & $8.8 \pm 0.5$ & $8.3 \pm 0.3$ & $15.2 \pm 0.1$ & $12.4 \pm 0.1$ & $11.8 \pm 0.1$ \\
$\mathrm{Fe}$ & $3.4 \pm 0.1$ & $3.3 \pm<0.1$ & $3.1 \pm 0.1$ & $2.0 \pm 0.1$ & $1.5 \pm<0.1$ & $1.4 \pm<0.1$ \\
$\mathrm{~K}$ & $3.6 \pm 0.1$ & $4.0 \pm 0.1$ & $6.5 \pm 0.3$ & $5.2 \pm 0.1$ & $4.4 \pm 0.1$ & $6.8 \pm 0.1$ \\
$\mathrm{Mg}$ & $1.6 \pm<0.1$ & $1.6 \pm 0.1$ & $1.4 \pm<0.1$ & $1.8 \pm<0.1$ & $1.5 \pm<0.1$ & $1.4 \pm<0.1$ \\
$\mathrm{Na}$ & $0.1 \pm<0.1$ & $2.9 \pm 0.1$ & $2.2 \pm 0.1$ & $0.2 \pm<0.1$ & $3.1 \pm 0.1$ & $2.5 \pm<0.1$ \\
$\mathrm{P}$ & $3.3 \pm 0.1$ & $3.1 \pm 0.2$ & $2.9 \pm<0.1$ & $4.0 \pm<0.1$ & $3.2 \pm<0.1$ & $3.1 \pm 0.1$ \\
$\mathrm{~S}$ & $0.1 \pm<0.1$ & $5.5 \pm<0.1$ & $5.4 \pm 0.1$ & $0.4 \pm<0.1$ & $4.6 \pm 0.1$ & $5.0 \pm 0.1$ \\
$\mathrm{Si}$ & $13.0 \pm 0.2$ & $12.4 \pm<0.1$ & $11.6 \pm 0.4$ & $17.0 \pm 1.0$ & $15.8 \pm 0.5$ & $14.9 \pm 0.2$ \\
\hline
\end{tabular}

GR and ASH (including $23 \mathrm{wt} . \%$ chicken manure) were mixed with alkali additives: once with sodium sulfate (products of thermochemical treatment named $\mathrm{ASH}+\mathrm{Na}$ and $\mathrm{GR}+\mathrm{Na}$ ) and once with a mixture of sodium and potassium sulfate (products of thermochemical treatment named $\mathrm{ASH}+\mathrm{Na} / \mathrm{K}$ and $\mathrm{GR}+\mathrm{Na} / \mathrm{K})$. Mixing ratios are displayed in Table A1. The mixtures were treated in corundum crucibles with lids at $1000{ }^{\circ} \mathrm{C}$ for $30 \mathrm{~min}$. in a stationary furnace (LH 15/14, Nabertherm $\mathrm{GmbH}$, Lilienthal, Germany). The potassium contents in $\mathrm{GR}+\mathrm{Na} / \mathrm{K}$ and $\mathrm{ASH}+\mathrm{Na} / \mathrm{K}$ were adjusted to a weight ratio $\mathrm{K} / \mathrm{P}=2.2$ by addition of the potassium sulfate to meet the common $\mathrm{K}$ to $\mathrm{P}$ ratio of soybean fertilizers (weight ratio $\mathrm{K} / \mathrm{P}=2$ ) [44].

All ashes and thermochemical products were pulverized $(\leq 250 \mu \mathrm{m})$ and used as P-fertilizers for soybeans in greenhouse pot experiments, as well as conventional $\mathrm{P}$ extraction tests, crystalline phase analysis, i.e. $\mathrm{XRD}$, and, in case of GR, used for liquid ${ }^{31} \mathrm{P}$ nuclear magnetic resonance (NMR) analyses and soil tests (Mehlich-I and DGT) (Figure 1).

\subsection{Greenhouse Pot Experiments}

Two independent and randomized greenhouse pot experiments were conducted at Forschungszentrum Jülich, IBG-2: Plant Sciences, Germany (location: 50 54'36"N, $6^{\circ} 24^{\prime} 49^{\prime \prime} \mathrm{E}$ ), to investigate the effects of thermochemical treatments on P-availability from bagasse-based ashes for soybeans (Glycine max (L.), Merr. var. RGT Shouna). Soybeans received $16 \mathrm{~h}^{\text {light day }}{ }^{-1}$ in the form of natural and artificial light ( $\geq 400 \mu \mathrm{mol} \mathrm{s}^{-1} \mathrm{~m}^{-2}$, SON-T AGRO 400, Phillips) regulated by an automated light system. Air temperature and $\mathrm{CO}_{2}$ averaged around $25 / 20{ }^{\circ} \mathrm{C}$ (day/night) and $400 \mathrm{ppm}$ and humidity was kept constant at $50-60 \%$ (day/night).

Soybean seeds were pre-germinated on moist filter paper in the dark for 3 days (d). Seedlings with comparable root lengths were then transplanted into nutrient-poor substrate $(0.05 \mathrm{wt} . \% \mathrm{~N}, 0.01 \mathrm{wt} . \% \mathrm{P}$, and $1.32 \mathrm{wt.} \% \mathrm{~K}$ ), which consisted of sand [45] and Null-Erde (Balster Einheitserdewerk, Fröndenberg, Germany) in a ratio of 1:1 by volume. In the stage of fully expanded unifoliate leaves, the roots were washed and plantlets with comparable root length, height and leaf area were inoculated with atmospheric $\mathrm{N}_{2}$-fixing Bradyrhizobium japonicum (NPPL HI Stick, BASF SE, Ludwigshafen, Germany) and transplanted into pots containing 1300 g, i.e., $1 \mathrm{~L}$, of air dried Oxisol $(0.10 \mathrm{wt} . \% \mathrm{~N}, 0.04 \mathrm{wt} . \% \mathrm{P}$, and 0.07 wt.\% K, Brazilian Federal University of Goiás, Goiânia, Brazil).

Prior to transplanting, the Oxisol received either no additional P (negative control, named No-P) or $100 \mathrm{mg} \mathrm{P} \mathrm{kg}^{-1}$ Oxisol from homogeneously incorporated fertilizers described in Table 1 . The dosage of $100 \mathrm{mg} \mathrm{P} \mathrm{kg}-1$ Oxisol was equivalent to $90 \mathrm{~kg} \mathrm{P}_{2} \mathrm{O}_{5} \mathrm{ha}^{-1}$ based on a planting density of $3 \times 10^{5}$ soybeans $\mathrm{ha}^{-1}$. The concentration of $\mathrm{K}$ in No-P, GR, GR+Na, ASH, and ASH+Na was 
adjusted to the $\mathrm{K}$ supply of the variants $\mathrm{GR}+\mathrm{Na} / \mathrm{K}$ and $\mathrm{ASH}+\mathrm{Na} / \mathrm{K}$, respectively. To avoid $\mathrm{K}$ - and $\mathrm{N}$-deficiency, all fertilization treatments, including the No-P control, received equivalent amounts of $56.5 \mathrm{~kg} \mathrm{~K} \mathrm{ha}^{-1}\left(68 \mathrm{~kg} \mathrm{ha}^{-1}\right.$ of $\left.\mathrm{K}_{2} \mathrm{O}\right)$ in the form of $\mathrm{K}_{2} \mathrm{SO}_{4}$ and $7 \mathrm{~kg} \mathrm{ha}^{-1}$ of $\mathrm{N}$ in the form of ammonium nitrate $\left(\mathrm{NH}_{4} \mathrm{NO}_{3}\right)$. These are the recommended amounts for soybeans growing in central western Brazil [44], where the soil originated.

Unfertilized Oxisol contained $3.3 \mathrm{mg} \mathrm{P} \mathrm{kg}^{-1}$ Oxisol extractable with Mehlich-I solution; and the $\mathrm{pH}$ ranged around $5.36 \pm 0.05$. The Oxisol mineral composition was around $38.8 \mathrm{wt} . \%$ clay, $16.8 \mathrm{wt} . \%$ silt, and $44.5 \mathrm{wt} . \%$ sand. The maximum water holding capacity of the soil ( $\mathrm{WHC}_{\max }$ ) was $54 \mathrm{wt} . \%$ (54 $\mathrm{g}$ water/100 $\mathrm{g}$ soil). In both experiments, the water holding capacity was kept around $38 \%$ to avoid leaching of minerals and was monitored by weighing the pots weekly.

\subsubsection{GR-Based P-Fertilizer (First Experiment)}

The first experiment was performed in the period from March to May, 2018, and investigated the availability of $P$ from GR and its thermochemical products to soybeans. Each treatment, i.e., No-P, GR, $\mathrm{GR}+\mathrm{Na}$, and $\mathrm{GR}+\mathrm{Na} / \mathrm{K}$, was tested with four biological replicates (plants) that grew for $59 \mathrm{~d}$ in Oxisol. In total, the soybeans received $8683 \mathrm{mmol} \mathrm{m}^{-2}$ light irradiance. The plants were harvested and total dry biomass, biomass partitioning to the roots, uptake of $\mathrm{P}$ and residual $\mathrm{P}$ in Oxisol were evaluated (Figure 1).

\subsubsection{ASH-Based P-Fertilizer (Second Experiment)}

The second experiment was performed from June to July, 2018, and investigated the effect of ASH and its thermochemical products on growth of soybeans. Each treatment, i.e., No-P, ASH, ASH+Na, and $\mathrm{ASH}+\mathrm{Na} / \mathrm{K}$, was tested with five biological replicates (plants), which grew for $41 \mathrm{~d}$ in Oxisol. Due to faster growth of fertilized plants than observed in the first experiment, the growing period was shorter, which limited our non-invasive leaf area measurements in the "ScreenHouse" platform. The leaf areas were measured every $7 \mathrm{~d}$ to gain insight into plant growth dynamics. Soybeans were irradiated with $7797 \mathrm{mmol} \mathrm{m}^{-2}$ light in total. Analyses of total dry biomasses of plants, biomass partitioning to the roots, and shoot growth dynamics were performed (Figure 1), whereas chemical biomass and soil analyses were dispensed of, because the shoot growth and biomass data of ASH, $\mathrm{ASH}+\mathrm{Na}$, and $\mathrm{ASH}+\mathrm{Na} / \mathrm{K}$-fertilized soybeans were not statistically different.

\subsection{Sample Preparation and Analysis}

\subsubsection{Non-Invasive Measurements}

In the second experiment, the shoot area of soybeans was captured in the "ScreenHouse" platform, described in Nakhforoosh et al. [46] and Scharr et al. [47], once per week starting $7 \mathrm{~d}$ after transplanting. In brief, the soybeans were imaged from four sides, i.e., 0, 90, 180 and $270^{\circ}$ (Point Gray Grasshopper2, $5 \mathrm{MP}$ color camera, FLIR Integrated Imaging Solutions Inc., Richmond, BC, Canada) at a $45^{\circ}$ angle and the sum of the four pictures represented the projected shoot area of soybeans. The final images were taken one day before harvest, i.e., $40 \mathrm{~d}$ after transplanting. True leaf areas were measured after harvesting the plants (L-3100, Li-cor, Lincoln, NE, USA) and correlated highly with projected leaf areas of the plants $\left(R^{2}=0.98\right.$, Appendix A Figure A1).

\subsubsection{Harvest}

Around $250 \mathrm{~g}$ of soil were sampled from each pot. Plants were harvested and separated into roots, stems and leaves. This allowed analysis of the dry matter (DM) of the total plant (TPDM) from shoot and root organs, as well as biomass partitioning in response to different P-fertilization forms. In this study, we focused on biomass partitioning to the roots expressed as root mass fraction (RMF) (Equation 
(1)), as plants are known to increase the root length density to acquire limited P [48]. Biomass and soil samples were dried at $65^{\circ} \mathrm{C}$ and $30^{\circ} \mathrm{C}$, respectively until they reached a constant weight.

$$
\operatorname{RMF}\left(\mathrm{g} \mathrm{g}^{-1} \mathrm{TPDM}\right)=100 \times \frac{\mathrm{DM}_{\text {Root }}(\mathrm{g})}{\mathrm{DM}_{\mathrm{TPDM}}(\mathrm{g})}
$$

In the first experiment, soils from all replicates of a treatment were mixed and homogenized. These were ground in a vibrating tungsten-carbide cup mill (Siebtechnik GmbH, Mühlheim/Ruhr, Germany) and used for $\mathrm{pH}$ measurements, extraction of $\mathrm{P}$ (Mehlich-I), and for $\mathrm{DGT}_{\text {harvest }}$ measurements.

\subsubsection{Chemical Analysis of P for Calculation of P Uptake}

The dried biomasses from the first experiment were ground (Retsch Mixer Mill MM 400, Retsch $\mathrm{GmbH}$, Haan, Germany) for chemical analysis of P. In the second experiment, P was not measured in the biomass of soybean plants because leaf area, total dry matter and biomass partitioning to the roots of $\mathrm{ASH}, \mathrm{ASH}+\mathrm{Na}$, and $\mathrm{ASH}+\mathrm{Na} / \mathrm{K}$-fertilized plants did not statistically differ. Fifty grams of biomass were digested with $2.0 \mathrm{~mL}$ of $\mathrm{HNO}_{3}$ and $1.0 \mathrm{~mL}$ of $\mathrm{H}_{2} \mathrm{O}_{2}$ in triplicate in a microwave (Mars 5, Prg. Pflanzen160 X-Press, Kamp-Lintfort, Germany). Afterwards, the samples were diluted with ultrapure water (Milli-Q Reference, Merck, Darmstadt, Germany) to a total volume of $14.0 \mathrm{~mL}$. Before measuring $P$ in inductively coupled plasma optical emission spectrometry (iCAP 6500, Fisher Scientific, Schwerte, Germany), subsamples were diluted to a ratio of 1: 20 . The standard deviations were 5 to $10 \%$.

The estimation of $\mathrm{P}$ uptake was based on the calculation reported by Thind et al. [7], and was modified through inclusion of the second harvest, as fertilization started with pre-cultivated soybeans. The uptakes of $\mathrm{P}$ were based on total amounts of $\mathrm{P}$ in the biomass of soybeans harvested at the time of fertilization began $\left(\mathrm{P}_{\text {fertilization beginning }}\right)$ and after $59 \mathrm{~d}$ growth $\left(\mathrm{P}_{\text {final harvest }}\right)$ in Oxisol (see Equation (2)).

$$
\Delta \mathrm{P} \text { uptake }(\mathrm{mmol})=\mathrm{P}_{\text {final harvest }}(\mathrm{mmol})-\mathrm{P}_{\text {fertilization beginning }}(\mathrm{mmol})
$$

\subsubsection{Determination of $\mathrm{pH}$ Value and LOI}

The $\mathrm{pH}$ value for all soils and fertilizer samples (Figure 1) were determined in $0.01 \mathrm{M} \mathrm{CaCl}_{2}$ solution (soil: solution ratio: 1: $2.5 w / v)$. For determination of LOI (Figure 1), $0.5 \mathrm{~g}$ of fertilizer was thermally treated at $550^{\circ} \mathrm{C}$ for $12 \mathrm{~h}$ under an oxidizing atmosphere in a stationary furnace (LH 15/14, Nabertherm GmbH, Lilienthal, Germany).

\subsubsection{Chemical Extraction of Soils}

Mixed and homogenized soil samples fertilized with GR, GR+Na, and GR+Na/K and the negative control 'No-P' were extracted in duplicate using aqua regia [49] and Mehlich-I (diluted $\mathrm{HCl} / \mathrm{H}_{2} \mathrm{SO}_{4}$ solution, 1: $4 w / v, 5 \mathrm{~min}$ [50]) after harvest (Figure 1). The P concentrations of all soil extracts were analyzed using inductively coupled plasma mass spectrometry (Thermo iCAP Q, Thermo Fisher, Dreieich, Germany).

\subsubsection{Chemical Extraction of Fertilizers}

The P-fertilizers were extracted (Figure 1) with $2 \%$ CA (fertilizer: solution ratio 1:100 w/v, $30 \mathrm{~min}$ ), NAC (fertilizer: solution ratio 1:100 w/v, $60 \mathrm{~min}$ at $\left.65^{\circ} \mathrm{C}\right)$, and $2 \%$ FA $(1: 100 w / v, 30 \mathrm{~min})$ carried out according to the EU regulation No. 2003/2003 [51] in duplicate. For extractions, $0.1 \pm 0.01 \mathrm{~g}$ of fertilizer was weighed and mixed with $4.0 \mathrm{~mL}$ of concentrated nitric acid $\left(\mathrm{HNO}_{3}\right), 1.5 \mathrm{~mL}$ perchloric acid $\left(\mathrm{HClO}_{4}\right)$, and $1.0 \mathrm{~mL}$ hydrofluoric acid $(\mathrm{HF})$ and subsequently digested in a microwave (mikroPrepA, MLS GmbH, Leutkirch, Germany). Excess HF was complexed with $5.0 \mathrm{~mL}$ of cold, saturated boric acid $\left(\mathrm{HBO}_{3}\right)$. The $\mathrm{P}$ concentrations from these chemical extraction tests and total digests of fertilizers were analyzed using inductively coupled plasma optical emission spectrometry (Thermo iCAP 7400, Dreieich, Germany). 


\subsubsection{DGT Experiments with Soils and Fertilizers}

The DGT device consists of a binding layer, a diffusion gel and a filter (to protect the gel) assembled in a plastic holder. The dissolved and labile $\mathrm{P}$ fraction of the soils and fertilizer from moist fertilizer/soil mixtures diffuses through the filter and the diffusion gel and is then adsorbed on a P selective binding layer. Two different types of experiments were carried out using the DGT method (Figure 1). $D_{G T} T_{\text {incubation }}$ experiments were conducted in duplicate with a mixture of fertilizers and original Oxisol soil analogous to the greenhouse pot experiments. DGT harvest were carried out in duplicate with mixed and homogenized soil samples from the greenhouse pot experiments after harvest. The procedure used in the DGT experiments was the same as described in Vogel et al. [30]. The only difference was that the adjusted water content for DGT application, which was in our experiment, was below $\mathrm{WHC}_{\max } .50 \%$ WHC was enough to achieve a glistering liquid paste which was due to the characteristics of Oxisol soil. The $\mathrm{P}$ concentrations from these extracts were analyzed by inductively coupled plasma mass spectrometry (Thermo iCAP Q Thermo Fisher, Dreieich, Germany).

\subsubsection{Crystalline Phase Analysis of Fertilizers by XRD}

Powder XRD measurements of the fertilizer samples (Figure 1) were performed in Bragg-Brentano geometry over a 20 range from $5^{\circ}$ to $80^{\circ}$, with a step size of $0.02^{\circ}$ (D8 Advance, Bruker AXS, Germany). The diffraction patterns were collected using $\mathrm{Cu} \mathrm{K}_{\alpha 1} / \mathrm{K}_{\alpha 2}\left(\lambda_{1}=1.54056 \AA / \lambda_{2}=1.54443 \AA\right)$ radiation. The diffraction patterns were recorded with a Lynxeye detector and evaluated using the Match! Software (version 3.6) (Crystal Impact GbR, Bonn, Germany).

\subsubsection{Identification and Quantification of P-Species with Liquid ${ }^{31} \mathrm{P}-\mathrm{NMR}$}

${ }^{31}$ P NMR analyses were performed to identify organic P-species in GR-based fertilizers (Figure 1), as GR contained 36 wt.\% LOI (Table 1). The term P-species describes how the P occurs in GR and its thermochemical products (e.g., monoester, diester, ortho-, pyro-, and polyphosphate).

Prior to NMR analysis, samples were extracted with $0.25 \mathrm{M} \mathrm{NaOH}$ and $0.05 \mathrm{M}$ ethylenediaminetetraacetic acid (EDTA) and centrifuged [52]. The supernatant was frozen and lyophilized. A total of $200 \mathrm{mg}$ of freeze-dried solids were dissolved in in a mixture of NaOD and $\mathrm{D}_{2} \mathrm{O}$ at $\mathrm{pH}$ 13. Methylenediphosphonic acid was added as internal reference [53]. Solution ${ }^{31} \mathrm{P}-\mathrm{NMR}$ spectra were obtained using a Bruker Avance III $600 \mathrm{MHz}$ spectrometer (Bruker Biospin, Rheinstetten, Germany) equipped with a Prodigy-cryoprobe.

\subsection{Statistics}

Total dry biomasses, root mass fractions and P uptakes in the first experiment (four biological replicates) and estimated leaf areas, total dry biomasses and root mass fractions in the second experiment (five biological replicates) were subjected to homogeneity of variance analyses (Bartlett's test, RStudio, 1.2.1335, package multcomp), descriptive statistics, Pearson chi-square test for normality analyses before a one-way ANOVA and Pearson's product-moment correlation analyses (RStudio, package agricolae) were performed. The means of replicates per fertilization treatment were compared by Tukey's honest significance test. The significance was determined at $p<0.05$, and different letters in the figures and tables indicate significant differences between the means. "Estimated and true leaf areas" and "P uptakes and total dry matters from shoot and root organs" were subjected to Pearson's product-moment correlation analyses. The figures were generated by using RStudio 1.2.1335, gg-plot, (TPDM, RMF, P uptake and estimated leaf areas) and origin $2018 \mathrm{G}$ (extractable P in CA, FA and NAC as well as linear regressions of $P$ uptake and TPDM with P from Mehlich-I, DGT incubation $_{\text {and }}$ $\left.\mathrm{DGT}_{\text {harvst }}\right)$. The values show means \pm standard error of means. 


\section{Results}

\subsection{Gasification Residue and Its Thermochemical Products}

\subsubsection{Chemical Extraction and P-Phase Analysis}

In general, the thermochemical treatment leads to decreasing mass fractions of $\mathrm{P}$ and other elements due to dilution by the alkali additives. At the same time, the mass fractions of $\mathrm{Na}$ and $\mathrm{K}$ increase (Table 1). In the case of GR-based fertilizers, the decrease of element mass fractions by thermochemical treatment is less pronounced, as the LOI of GR decreases from 36 wt.\% to 8 wt.\% during the thermochemical treatment (Table 1).

The extractable P increased from $40 \%$ in NAC and $60 \%$ in FA to around $80 \%$ of total P in both NAC and FA due to thermochemical treatment of GR with $\mathrm{Na}_{2} \mathrm{SO}_{4}$ and $\mathrm{Na}_{2} \mathrm{SO}_{4} / \mathrm{K}_{2} \mathrm{SO}_{4}$ (Figure 2). Contrary to the extractions in NAC and FA, the extractable P in CA was already $80 \%$ in GR and increased to $90 \%$ of total $\mathrm{P}$ in $\mathrm{GR}+\mathrm{Na}$ and $\mathrm{GR}+\mathrm{Na} / \mathrm{K}$ (Figure 2).

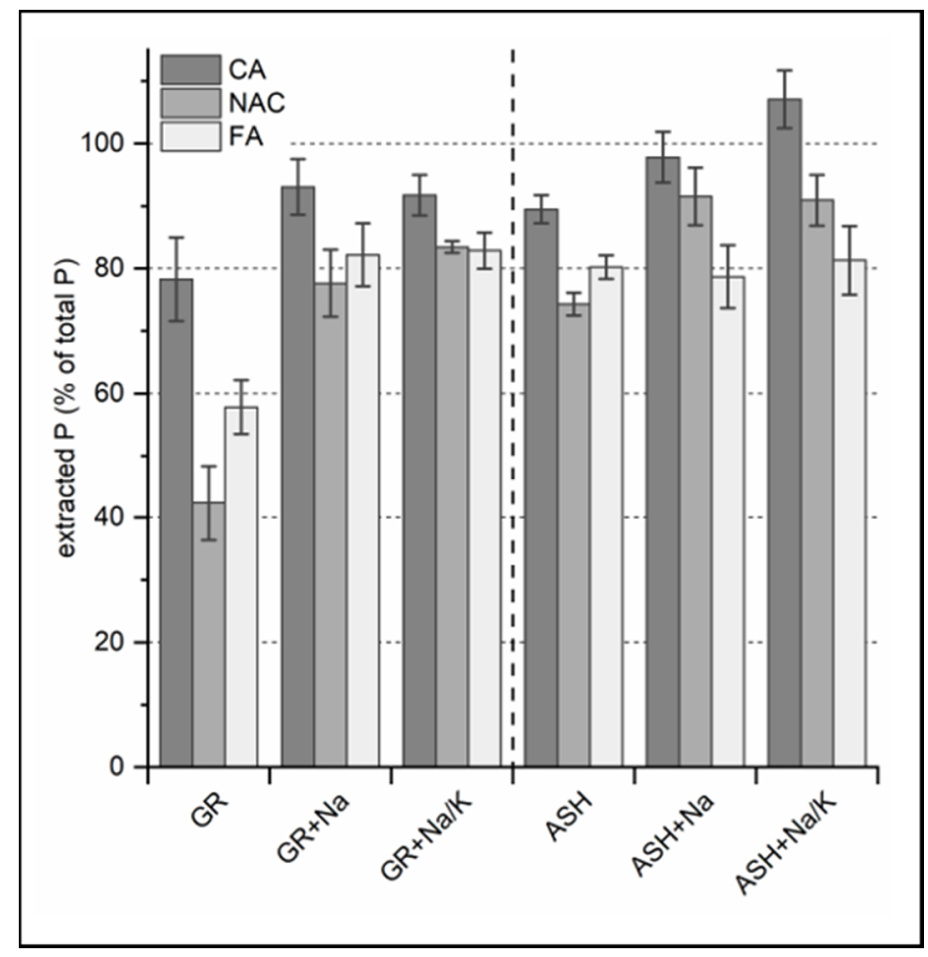

Figure 2. Fractions of CA-, NAC-, and FA-extractable $\mathrm{P}$ related to total $\mathrm{P}$ from GR and $\mathrm{ASH}$ and their products after thermochemical treatments with $\mathrm{Na}_{2} \mathrm{SO}_{4}(\mathrm{GR}+\mathrm{Na}$ and $\mathrm{ASH}+\mathrm{Na})$ and $\mathrm{Na}_{2} \mathrm{SO}_{4} / \mathrm{K}_{2} \mathrm{SO}_{4}$ $(\mathrm{GR}+\mathrm{Na} / \mathrm{K}$ and $\mathrm{ASH}+\mathrm{Na} / \mathrm{K})$. All values are means \pm standard error of means (duplicate measurements).

Sections of diffraction patterns are depicted in Figure A2. All samples contained an amorphous phase visible as an increased background intensity between $20^{\circ}$ and $38^{\circ} 2$ theta (Figure A2), which complicated the identification of the structural phases of P. Reflexes in these diffraction pattern could be correlated with crystalline phases. A more detailed description of phases that do not contain $\mathrm{P}$ is available in Table A2. These phases are not further considered, as they are not relevant for P-fertilization.

Whitlockite $\left(\mathrm{Ca}_{9} \mathrm{M}\left(\mathrm{PO}_{4}\right)_{7}\right.$, where $\mathrm{M}$ is most commonly $\mathrm{Ca}, \mathrm{Fe}$, and/or $\mathrm{Mg}$ ) was detected as the main crystalline P-phase and $\mathrm{CaK}_{2} \mathrm{P}_{2} \mathrm{O}_{7}$ as minor crystalline P-phase in GR by XRD analyses. In GR+Na and $\mathrm{GR}+\mathrm{Na} / \mathrm{K}$ products, whitlockite remained present in minor amounts (Table 2). The crystalline phase $\mathrm{CaNaPO}_{4}$ was most abundant in thermochemical GR+Na and GR+Na/K products, which was due 
to the reaction of the P-phases with $\mathrm{Na}_{2} \mathrm{SO}_{4}$ under reducing conditions. However, no K-containing crystalline P-phase was detected in the sample $\mathrm{GR}+\mathrm{Na} / \mathrm{K}$, although $\mathrm{K}_{2} \mathrm{SO}_{4}$ was added as an additive.

Table 2. P-phases related to extractable P in CA and NAC. Overview of P-phases was based on Figures A2 and A6, as well as interpretation from Ando et al. [54], Bergfeldt et al. [18], and Kratz et al. [19]. Meaning of symbols: '-' not present $\bigcirc$ low amount, $\bigcirc$ high amount, $\bigcirc$ only one P-phase identified. This quantification is a rough semi-quantification with comparison of reflex intensity and further information about extractable $\mathrm{P}$ and chemical composition. ${ }^{1}$ two 'undefined P-Phases', extractable in FA and/or CA.

\begin{tabular}{|c|c|c|c|c|c|}
\hline & \multicolumn{5}{|c|}{ P-Extractability in CA and NAC } \\
\hline & \multicolumn{2}{|c|}{ Lower } & \multicolumn{3}{|c|}{ Higher } \\
\hline & $\begin{array}{l}\text { Whitlockite } \\
\text { Cag } \mathrm{M}\left(\mathrm{PO}_{4}\right)_{7}\end{array}$ & Undefined $^{1}$ & $\begin{array}{c}\text { Pyro-Phosp. } \\
\mathrm{CaK}_{2} \mathrm{P}_{2} \mathrm{O}_{7}\end{array}$ & $\mathrm{Ca}(\mathrm{Na}, \mathrm{K}) \mathrm{PO}_{4}$ & $\mathrm{CaNaPO}_{4}$ \\
\hline GR & 0 & - & 0 & - & - \\
\hline $\mathrm{GR}+\mathrm{Na}$ & 0 & - & - & - & \\
\hline $\mathrm{GR}+\mathrm{Na} / \mathrm{K}$ & 0 & - & - & - & \\
\hline ASH & - & 0 & - & 0 & - \\
\hline $\mathrm{ASH}+\mathrm{Na}$ & - & - & - & - & \\
\hline $\mathrm{ASH}+\mathrm{Na} / \mathrm{K}$ & - & - & - & - & \\
\hline
\end{tabular}

GR contained $36 \mathrm{wt} . \%$ LOI, which promoted us to conduct liquid ${ }^{31} \mathrm{P}$ NMR analyses to identify organic P. However, no organic $\mathrm{P}$ species were detected in either GR, GR+Na, or GR+Na/K. In these fertilizers only Ortho-P and Pyro-P were identified (Figure A3).

\subsubsection{P-Fertilization Effects}

The fertilizations of Oxisol soil with GR, GR+Na, and GR+Na/K increased the $\mathrm{pH}$ levels from 5.4 (negative control treatment, No-P) to around 5.7 (Table A3).

Compared to negative control plants (No-P), fertilizations with GR and its thermochemical products improved the shoot growth (Figure $3 \mathrm{~A}$ ) and significantly increased the total plant dry matter of soybeans as compared to unfertilized plants (Figure 3B). Total dry biomass from shoot and root organs was highly correlated with the uptake of $P\left(R^{2}=0.96\right.$, Figure A4) and both significantly increased for $\mathrm{GR}+\mathrm{Na}$ and $\mathrm{GR}+\mathrm{Na} / \mathrm{K}$ fertilization compared to GR fertilization (Figure 3B,C). Biomass partitioning to the roots decreased following fertilization with GR and its thermochemical products. However, compared to negative control plants, this was statistically supported only for fertilization with GR+Na (Figure 3D).

\subsubsection{Correlations of Soil Tests (Mehlich-I and DGT) to P Uptake by Soybeans}

DGT $_{\text {incubation }}$ (Figure 3E) can predict the availability of P from GR, GR+Na, and GR+Na/K to soybeans under lab conditions, whereas DGT $_{\text {harvest }}$ (Figure $3 \mathrm{~F}$ ) and the standard extraction methods for $\mathrm{P}$ in Oxisol soil, i.e., Mehlich-I [25], represent residual $\mathrm{P}$ in the soil after plant growth experiments. The measured concentrations of adsorbed P by DGT harvest $\left(2\right.$ to $20 \mu \mathrm{g} \mathrm{P} \mathrm{L}^{-1}$ ) was lower compared to

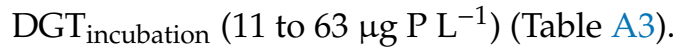

Extractable $\mathrm{P}$ in soil and the results of greenhouse pot experiments, i.e. P uptake by plants (Figure 3E-G) and total plant dry matter from shoot and root organs (Figure A5), were correlated. In general, the linear regressions showed lower correlations of Mehlich-I and DGT to the P uptake by soybeans $\left(R^{2}>0.64\right)$ (Figure $\left.3 E-G\right)$ compared to the total plant dry matter $\left(R^{2}>0.87\right)$ (Figure A5), albeit the correlation trends were the same. However, the highest correlations were found for $\mathrm{P}$ uptake by soybeans with $D_{\text {GT }}$ harvest $\left(R^{2}=0.89\right)$, followed by DGT $T_{\text {incubation }}\left(R^{2}=0.84\right)$, and Mehlich-I solution 
$\left(R^{2}=0.64\right)$ (Figure 3E-G). The correlation coefficients of $P$ from $D G T_{\text {harvest }}, D_{\text {G }} T_{\text {incubation }}$ and from Mehlich-I extractions with total plant dry matter were 0.96, 0.92, and 0.87, respectively (Figure A5).

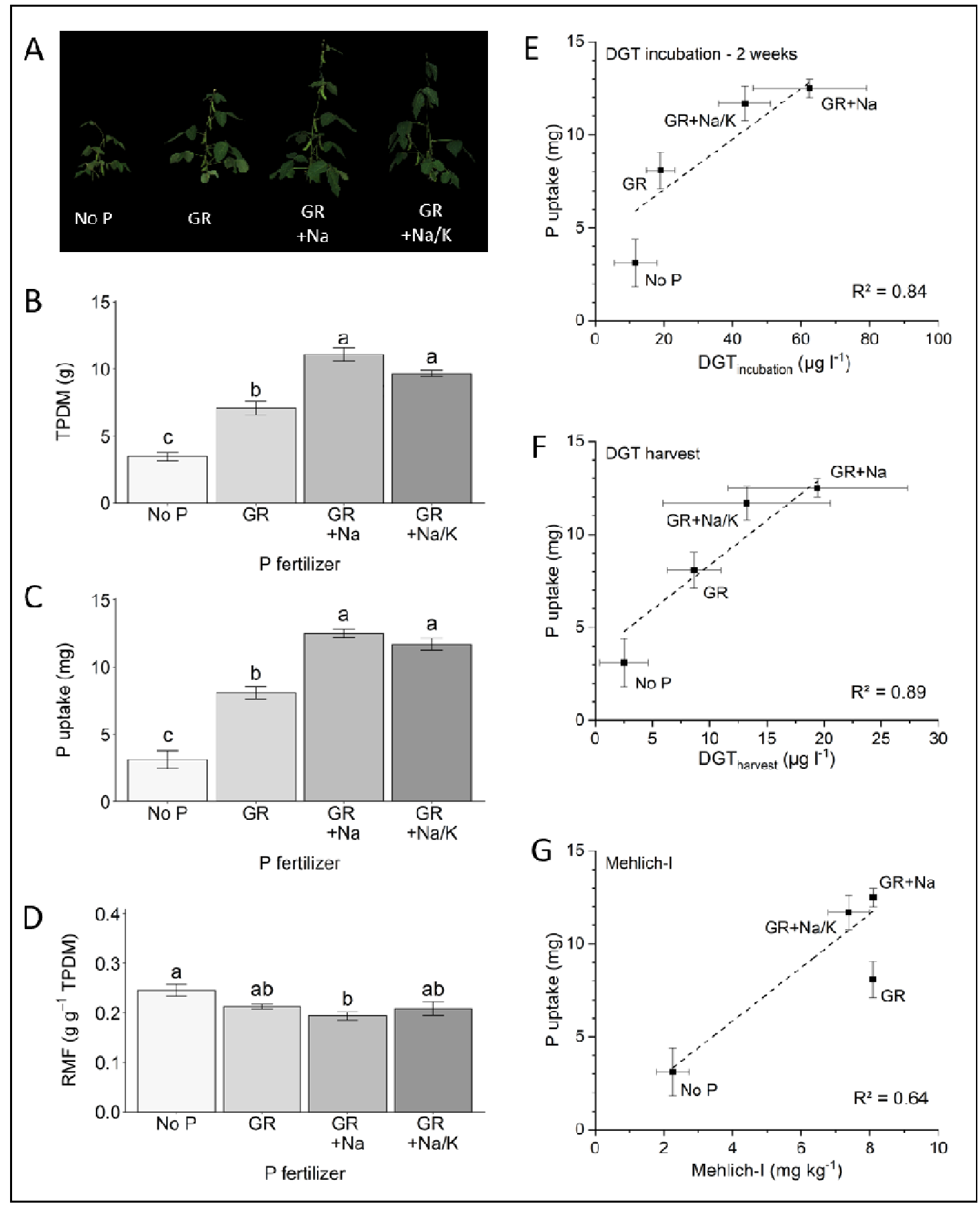

Figure 3. Soybean responses to GR-based P-fertilizers and linear correlations of $\mathrm{P}$ uptake by soybean plants vs. soil tests, i.e., DGT incubation, $_{\text {DGT }}$ harvest and Mehlich-I. (A) Shoot growths, (B) TPDM, (C) P

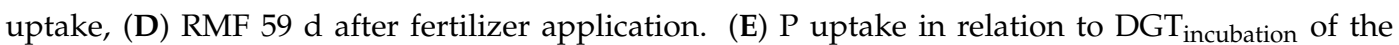

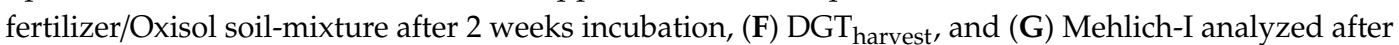
harvest. All values are means \pm standard error of means (vertical error bars in B-G: four biological replicates, and horizontal error bars in E-G: duplicate measurements). Identical letters present no significant difference (Tukey's test, $p<0.05$ ). 


\subsection{Combustion Ash and Its Thermochemical Products}

\subsubsection{Chemical Extraction and P-Phase Analysis}

The extractable P increased from around $80 \%$ in NAC and $90 \%$ in CA to around $90 \%$ and $100 \%$ of total $\mathrm{P}$ due to thermochemical treatments with $\mathrm{Na}_{2} \mathrm{SO}_{4}$ and $\mathrm{Na}_{2} \mathrm{SO}_{4} / \mathrm{K}_{2} \mathrm{SO}_{4}$, respectively (Figure 2). Contrary to the extractions in NAC and CA, the extractable P in FA remained at around $80 \%$ even after thermochemical treatments with $\mathrm{Na}_{2} \mathrm{SO}_{4}$ and $\mathrm{Na}_{2} \mathrm{SO}_{4} / \mathrm{K}_{2} \mathrm{SO}_{4}$ (Figure 2).

Identification of crystalline P-phases was difficult because four common P-bearing phases, such as apatite, whitlockite, $\mathrm{AlPO}_{4}$, and pyrophosphates, could not be identified by XRD in ASH (Figure A6). In order to identify the possible P-bearing crystalline phases, the ash was extracted with NAC, FA, or CA accompanied by XRD investigations before and after extraction (Figure A7).

Calcium alkali phosphate was related to reflexes, which disappear after leaching with NAC, FA, and CA (Figure A7). The composition was approximately $\mathrm{Ca}_{2} \mathrm{NaK}\left(\mathrm{PO}_{4}\right)_{2}$ according to data base entry (International Centre for Diffraction Data Powder diffraction file entry 00-051-0579). A reflex shift in the diffractogram pattern indicated that this phase contained more $\mathrm{K}$ than $\mathrm{Na}$. Therefore, this crystalline P-phase was named with the general formula $\mathrm{CaNa}_{\mathrm{x}} \mathrm{K}_{1-\mathrm{x}} \mathrm{PO}_{4}(\mathrm{x}<0.5)$ or $\mathrm{Ca}(\mathrm{Na}, \mathrm{K}) \mathrm{PO}_{4}$.

Two further reflexes could not be associated with any known P-phase according to the data base. It is noticeable that these reflexes were shifted towards reflexes of known whitlockite phases. One reflex disappeared after leaching with $C A$ as well as with FA (phase $X_{1}$ ), whereas the other one disappeared after leaching with FA (phase $\mathrm{X}_{2}$ ) (Figure A7). However, these two P-phases in ASH were not clearly identified and are named 'undefined P-phases' in the following. Thermochemical treatments of ASH with $\mathrm{Na}_{2} \mathrm{SO}_{4}$ and $\mathrm{Na}_{2} \mathrm{SO}_{4} / \mathrm{K}_{2} \mathrm{SO}_{4}$ transformed all detected crystalline P-phases to $\mathrm{CaNaPO}_{4}$, while $\mathrm{Ca}(\mathrm{Na}, \mathrm{K}) \mathrm{PO}_{4}$ and the 'undefined P-phases' disappeared (Table 2).

\subsubsection{P-Fertilization Effects of ASH-Based Fertilizers}

To investigate the shoot growth dynamics of soybeans receiving no-P, ASH, ASH+Na, and $\mathrm{ASH}+\mathrm{Na} / \mathrm{K}$, non-invasive measurements of leaf area were taken. The availability of $\mathrm{P}$ caused deviations in leaf area. From $21 \mathrm{~d}$ after transplant until the end of the experiment, soybean growth without any P-fertilization was statistically shown to have the lowest estimated leaf area (no observed changes in the area of $100 \mathrm{~cm}^{2}$; Figure 4B). Although the leaf areas of soybeans of all three ash treatments enlarged significantly over time, there were no statistically significant differences between the fertilization treatments (Figure $4 \mathrm{~B}$ ). Over the course of $35 \mathrm{~d}$ of growth, i.e., from first to last measurement, soybeans receiving $\mathrm{P}$ from $\mathrm{ASH}, \mathrm{ASH}+\mathrm{Na}$, and $\mathrm{ASH}+\mathrm{Na} / \mathrm{K}$ increased the estimated leaf areas 6.8-, 8.1-, and 8.5-fold, respectively. Estimated leaf area (Figure 4B) and final shoot development (Figure 4A) were reflected in the total dry biomass of soybeans after $41 \mathrm{~d}$ growth, i.e. No-P control soybeans accumulated significantly less total dry biomass from shoot and root organs than ASH, $\mathrm{ASH}+\mathrm{Na}$, and $\mathrm{ASH}+\mathrm{Na} / \mathrm{K}$ fertilized plants (Figure $4 \mathrm{C}$ ). This was supported by biomass partitioning to the roots, as control soybeans partitioned significantly more biomass to the roots than plants fertilized by ASH and its thermochemical products (Figure 4D). However, while the estimated leaf area and total dry biomass accumulation seemed to depend on fertilization treatment, it did so without any statistical support (Figure 4B,C). The trend of higher availability of $\mathrm{P}$ from $\mathrm{ASH}+\mathrm{Na}$ and $\mathrm{ASH}+\mathrm{Na} / \mathrm{K}$ than from ASH alone affected biomass partitioning to the roots. Plants receiving $\mathrm{P}$ from $\mathrm{ASH}+\mathrm{Na}$ and $\mathrm{ASH}+\mathrm{Na} / \mathrm{K}$ tended to partition less biomass to the roots than plants fertilized by ASH alone (Figure 4D).

The soil $\mathrm{pH}$ levels were 5.3 in negative control treatment (No-P) and around 6 in ASH, $\mathrm{ASH}+\mathrm{Na}$, and $\mathrm{ASH}+\mathrm{Na} / \mathrm{K}$ fertilized soils (data not shown). No DGT analysis, Mehlich-I extraction, and measurement of $\mathrm{P}$ uptake were conducted with ASH and its thermochemical products because no significant differences in plant growth analyses were detected (Figure $4 \mathrm{~A}-\mathrm{D}$ ). 

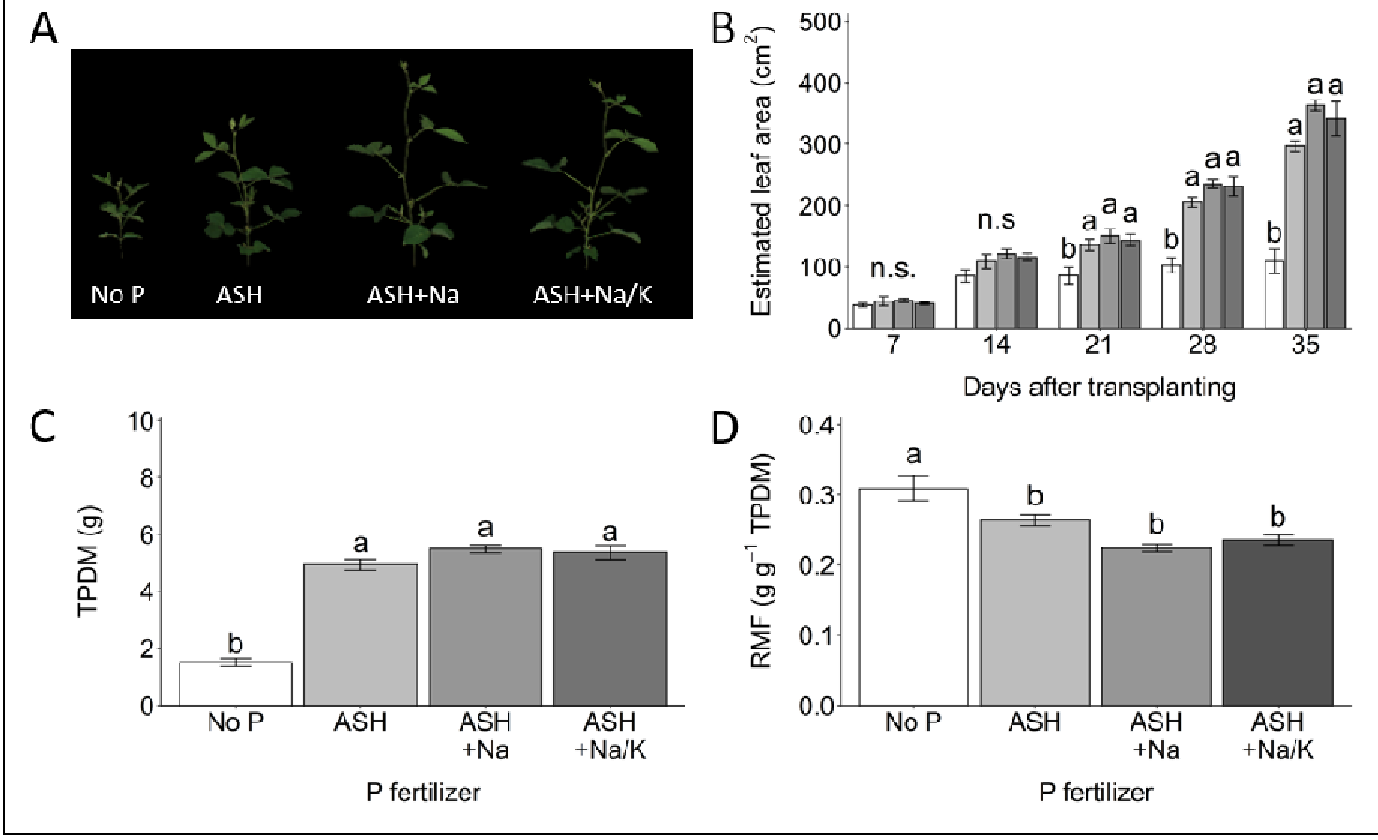

Figure 4. Responses of soybean seedlings to ASH-based P-fertilizers. (A) Soybean shoot growth, (B) estimated leaf areas of soybeans during the first $35 \mathrm{~d}$ after fertilizer application, (C) TPDM, and (D) RMF $41 \mathrm{~d}$ after fertilizer application. Identical letters present no significant difference (Tukey's test, $p<0.05$ ). All values are means \pm standard error of means (five biological replicates). Statistical differences of estimated leaf areas refer to different treatments within the same measuring day.

\section{Discussion}

\subsection{Gasification Residue (GR) and Its Thermochemical Products}

\subsubsection{Effect of Thermochemical Treatment on Plant Growth}

The positive fertilization effects of GR, GR+Na, and GR+Na/K were detected by improved shoot growth, significantly increased total plant dry matter from shoot and root organs, and uptake of P compared to control plants (Figure 3A-C). However, only fertilization with GR+Na significantly decreased the biomass partitioning to the roots (Figure 3D), indicating higher P-fertilization performance compared to GR and $\mathrm{GR}+\mathrm{Na} / \mathrm{K}$, as plants growing under nutrient deficient conditions invest their resources to increase the root density [48] and to increase the surface area of exchange between the roots and the rhizosphere [55]. Here, we did not consider the influence of differences in $\mathrm{K}$ and nitrogen $(\mathrm{N})$ availability, as these nutrients were provided in excess. Compared to unfertilized plants, the improved growth of soybeans with bagasse or bagasse-based ash fertilizers is in agreement with previous studies on lettuce and cucumber [56], corn [6], sugarcane [57], wheat [7,8], and bean and Chinese kale [58].

The positive effects of thermochemical treatments on plant $P$ availability from GR-based products to soybeans growing in acidic Oxisol soil (Figure 3A-C) are in agreement with previous studies reporting significant increases of $\mathrm{P}$ availability from sewage sludge ash-based products to maize growing in sandy soil [20], in nutrient-poor subsoil [21] and in sandy soil/quartz sand and loamy sand/quartz sand blends [22]. The increased availability of $\mathrm{P}$ derived from thermochemical treatment is further supported by extraction analyses in varying solutions (Figure 2).

\subsubsection{Extraction Methods and Crystalline Phase Composition}

Fertilization performance, which was determined by total dry biomass of soybean plants and $\mathrm{P}$ uptake, depended strongly on the extractable P (Figure 2) and the crystalline P-phase composition of GR, and its thermochemical products, GR+Na and GR+Na/K (Table 2). The extractable P of 
GR correlates with the extractable P of its main P-bearing crystalline phase whitlockite. Ando [54] investigated synthetized whitlockites and found extractable P in CA and NAC comparable to that found in GR. In contrast to whitlockite, $\mathrm{P}$ from the minor pyrophosphate compound $\mathrm{CaK}_{2} \mathrm{P}_{2} \mathrm{O}_{7}$ is completely extractable in NAC and CA [18]. The impact of $\mathrm{CaK}_{2} \mathrm{P}_{2} \mathrm{O}_{7}$ on the overall extractable $\mathrm{P}$ of GR was negligible due to its low concentration.

The extraction of $P$ from GR varied depending on the extractant, with extractable P lowest in NAC, medium in FA and highest in CA (Figure 2). The extraction of P with NAC, FA and CA depends on $\mathrm{pH}$ and the extraction mechanism. NAC extracts the lowest amount of $\mathrm{P}$ (Figure 2), as it acts solely as a complexing agent [59]. Contrary to NAC, FA has low complexing ability but acts through decreasing $\mathrm{pH}$, whereas CA combines the mechanisms of both FA and NAC as it is a weak acid and strong metal-complexing agent [59]. These findings suggest that the extraction and solubilization of $P$ by soybeans from whitlockite and other less prominent phosphates in GR require both characteristics of the extraction solutions, i.e. acidification of GR particles and complexing of $\mathrm{P}$ bearing ions.

The thermochemical treatment of GR with $\mathrm{Na}_{2} \mathrm{SO}_{4}(\mathrm{GR}+\mathrm{Na})$ and $\mathrm{Na}_{2} \mathrm{SO}_{4} / \mathrm{K}_{2} \mathrm{SO}_{4}(\mathrm{GR}+\mathrm{Na} / \mathrm{K})$ transformed whitlockite and $\mathrm{CaK}_{2} \mathrm{P}_{2} \mathrm{O}_{7}$ into $\mathrm{CaNaPO}_{4}$ (Table 2) is in agreement with previous studies [21,37]. Even though P from $\mathrm{CaNaPO}_{4}$ was reported to be completely extractable in CA [60], NAC [23] and FA [19], we found that extractable P ranged from 80 to 90\% (Figure 2) due to incomplete transformation of whitlockite into $\mathrm{CaNaPO}_{4}$ in $\mathrm{GR}+\mathrm{Na}$ and $\mathrm{GR}+\mathrm{Na} / \mathrm{K}$ (Table 2). This was caused by incomplete reaction between GR and the added alkali sulfates, observed as residual $\mathrm{Na}_{2} \mathrm{SO}_{4}$ and $\mathrm{K}_{3} \mathrm{Na}\left(\mathrm{SO}_{4}\right)_{2}$ remaining in $\mathrm{GR}+\mathrm{Na}$ and $\mathrm{GR}+\mathrm{Na} / \mathrm{K}$ (Figure A2 and Table A2). This transformation can most likely be improved by changing the solid/atmosphere ratio in the crucible trials, or the addition of a reducing agent, e.g., chicken manure, and should be investigated in future studies.

\subsubsection{Soil Tests}

To test if the fertilizer performance of $\mathrm{P}$ derived from GR and its thermochemical products using

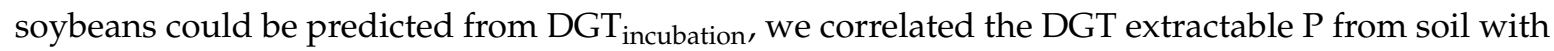
total plant dry matter yield and P uptake. DGT $\mathrm{T}_{\text {harvest }}$ and Mehlich-I measurements were performed and compared to the P-fertilization effect of GR, GR+Na, and GR-Na/K before and after (residual P) plant growth.

Results of DGT $\mathrm{Dincubation}_{\text {(Figure 3E) and DGT }}$ harvest (Figure 3F) showed realistic trends [30] but should be treated with caution due to the low number of data points and replicates. The high relative standard deviations of up to $55 \%$ observed for DGT $_{\text {harvest }}$ (Table A3) were most likely due to the low P-concentration ranges in the samples. Similar variance can also be found in the studies of Six et al. [27] and Vogel et al. [30].

The fertilization effects predicted from DGT $T_{\text {incubation }}$ correlated well with $P$ uptake $\left(R^{2}=0.89\right.$, Figure 3E). This method might be closer to the conditions in the field as DGT mimics the uptake of $\mathrm{P}$ by roots, unlike traditional extractions in solution. Correlation coefficients around $\mathrm{R}^{2}=0.90$ were reported by Vogel et al. [30] and Duboc et al. [29], which support our findings despite low replicate numbers and only four data points.

The correlation coefficient $R^{2}=0.89$ from DGT ${ }_{\text {harvest }}$ compared to $R^{2}=0.64$ from Mehlich-I extraction (Figure $3 \mathrm{~F}, \mathrm{G}$ ) led us to conclude that the $\mathrm{DGT}_{\text {harvest }}$ method better predicts the plant availability of $P$ remaining in acidic Oxisol than the extraction with Mehlich-I solution, even if DGT $_{\text {harvest }}$ has higher variance. Mehlich-I extraction is the most common procedure used to quantify extractable $\mathrm{P}$ in Oxisol soil in Brazil [25], but our results suggest that application of alternative methods such as DGT might improve prediction of available $\mathrm{P}$ and should be tested in Brazil under field conditions. 


\subsection{Different Phase Composition between GR and ASH}

To scrutinize the positive effect of the thermochemical treatment on plant $\mathrm{P}$ availability, we further compared the thermal conversion products from gasification (GR) with products from combustion (ASH).

The P-phases differed among the various products, even though thermal co-processing of bagasse pellets and chicken manure was used in the production of both GR and ASH (Table 2). This indicates that either the gasification or combustion process conditions or the different ratios of bagasse pellets to chicken manure affect the P-phase formation.

The reaction temperature and chemical composition of GR and ASH were most likely less relevant for different phase formations, as both processes reached maximum temperatures of around $800^{\circ} \mathrm{C}$ and the weight ratios of $\mathrm{K} / \mathrm{P}(1.1$ in GR and 1.3 in $\mathrm{ASH})$ are adequate to form $\mathrm{Ca}\left(\mathrm{Na}, \mathrm{K}^{2}\right) \mathrm{PO}_{4}$ [34]. The different ratios between bagasse pellets and chicken manure in GR (85:15 by weight) and in ASH (60:40 by weight) had no effect on the formation of P-phase, because the combustion of bagasse pellets and chicken manure in the ratio of 80:20 formed the same P-phases as ASH with $60 \mathrm{wt} . \%$ bagasse pellets and $40 \mathrm{wt} . \%$ chicken manure (data not shown). According to Christel et al. [17] and Bergfeldt et al. [18], processing conditions may affect the formation of P-phases in gasification residues and ashes. During co-combustion in the grate furnace, the contact time between ash particles from different origins was considerable, facilitating the formation of complex crystalline phases, such as $\mathrm{Ca}(\mathrm{Na}, \mathrm{K}) \mathrm{PO}_{4}, \mathrm{Ca}_{2} \mathrm{MgSi}_{2} \mathrm{O}_{7},(\mathrm{Na}, \mathrm{Ca})\left(\mathrm{Si}, \mathrm{Al}_{4} \mathrm{O}_{8}, \mathrm{NaAlSi}_{2} \mathrm{O}_{6}\right.$, and $\mathrm{KAlSi}_{2} \mathrm{O}_{6}$ (Figure A6). Compared to the grate furnace, the contact time between particles in a fluidized bed process is short, so the formation of complex crystalline phases in the co-gasification residue was limited. Consequently, only crystalline phases of simple chemical compositions, such as $\mathrm{Ca}_{9} \mathrm{M}\left(\mathrm{PO}_{4}\right)_{7}, \mathrm{CaK}_{2} \mathrm{P}_{2} \mathrm{O}_{7}, \mathrm{SiO}_{2}, \mathrm{CaCO}_{3}$, and $\mathrm{KCl}$, occurred in GR (Figure A2).

Bogush et al. [34] detected $\mathrm{Ca}(\mathrm{Na}, \mathrm{K}) \mathrm{PO}_{4}$ in chicken manure ash remaining after the combustion process. We conclude comparable $\mathrm{P}$ extractability from $\mathrm{ASH}$ and its thermochemical products is related to $\mathrm{Ca}(\mathrm{Na}, \mathrm{K}) \mathrm{PO}_{4}$ and $\mathrm{CaNaPO}_{4}$ (Table 2), as the two phases belong to the same phase system. Whitlockite is more stable than $\mathrm{Ca}(\mathrm{Na}, \mathrm{K}) \mathrm{PO}_{4}[19]$, which was reflected by lower extractability of $\mathrm{P}$ in CA, FA, and NAC from GR than from ASH (Figure 2).

\subsection{Thermochemical Treatment of ASH}

In the second greenhouse pot experiment, soybeans receiving P from $\mathrm{ASH}+\mathrm{Na}$ and $\mathrm{ASH}+\mathrm{Na} / \mathrm{K}$ accumulated more total dry biomass than ASH fertilized plants, albeit without any statistical support (Figure 4C). Increased biomass accumulation is related to $\mathrm{P}$ availability, demonstrated by the linear correlation in GR-, GR+Na-, and GR+Na/K-fertilized soybean plants $\left(R^{2}=0.96\right.$; Figure A4). Higher availability of $\mathrm{P}$ from $\mathrm{ASH}+\mathrm{Na}$ and $\mathrm{ASH}+\mathrm{Na} / \mathrm{K}$ than from $\mathrm{ASH}$ was in accordance with the crystalline P-phases (Table 2) and CA and NAC extractable P (Figure 2). The lower extractability and availability of $\mathrm{P}$ from ASH to soybeans was probably due to the presence of two 'undefined P-phases' which were less soluble than $\mathrm{CaNaPO}_{4}$ (Table 2). Thus, fertilization of plants with ASH, providing highly soluble $\mathrm{Ca}(\mathrm{Na}, \mathrm{K}) \mathrm{PO}_{4}$ (Table 2), resulted in leaf areas comparable to those of soybeans fertilized with $\mathrm{ASH}+\mathrm{Na}$ and $\mathrm{ASH}+\mathrm{Na} / \mathrm{K}$ during the first three weeks of growth (Figure 4B). We suggest that the lower availability of $P$ from the "undefined P-phases" (Table 2) limited the leaf area development of soybeans in the later growth phases (Figure 4).

Soybeans, and plants in general, secrete a range of organic acids [61,62] that can acidify the rhizosphere and/or complex metal ions promoting P solubilization [63-65]. This activity can depend on the local soil conditions. Also, adaptations of root system architecture to specific soil conditions are instrumental in increasing P uptake $[61,65]$. These mechanisms may further affect how efficiently soybeans obtain P from GR, ASH, root mass fraction (RMF) and their thermochemical products. Thus, the P-fertilization performance of the products needs to be further investigated in long-term experiments which take species-specific plant traits into account. 


\section{Conclusions}

We tested thermal co-conversion products of sugarcane bagasse- and chicken manure as P-fertilizer for soybeans. Thermochemical treatments increased the availability of $\mathrm{P}$ from the bagasse-based products to soybeans compared to untreated ashes, due to the formation of crystalline calcium sodium phosphate.

The identification of the crystalline P-phases allowed us to predict the amount of extractable $\mathrm{P}$ and, thus, the fertilization performance of bagasse-based gasification residues, ashes and their thermochemical products to soybeans growing in acidic Oxisol. However, the efficiency of thermochemical post-treatment is negligible if calcium alkali phosphates are already present in co-combusted bagasse/chicken manure ash prior to the thermochemical treatment.

Furthermore, the DGT approach was highly correlated with soybean P uptake and total plant biomass accumulation, suggesting it as a more reliable predictor of plant-available $\mathrm{P}$ than extraction in Mehlich-I solution. This should be further studied under field conditions.

\section{Outlook}

Thermochemical post-treatments increased plant availability of P from GR- and ASH-based products and further analyses should now identify the effects of chicken manure in bagasse-based products and processing effects on P-phases. In addition, further understanding the role of extractable $\mathrm{P}$ and its availability to soybeans and other plants, primarily sugarcane, can help make progress in the closing of nutrient cycles. To conclusively estimate the availability of $P$ from bagasse-based ashes, more detailed plant experiments are crucial, since plant roots and associated microorganisms actively modify the rhizosphere environment to mobilize P. When discussing ash-based fertilizers for application in agricultural contexts, experiments under field conditions using locally relevant agricultural practices are particularly indispensable, since biotic and abiotic factors may influence the availability of $P$ to plants. Furthermore, studies under field conditions are needed to confirm superiority of novel DGT methods over the commonly used standard methods of Mehlich-I, calcium acetate lactate (CAL), and Olsen.

Author Contributions: The conceptualization and methodology of the study was realized and approved by H.H., V.D., S.D.S., and C.A.; principal investigation, formal data analysis and visualization, H.H. and V.D.; additional investigation, C.V., S.W., G.V.L., M.M., and F.M.; the original draft was written by H.H., V.D., S.D.S., and C.A.; all authors reviewed, edited and approved the final manuscript; main resources for the experiments were provided by J.W.Z., W.A.d.F.-Z., M.M., and F.M.; funding acquisition, J.W.Z., W.A.d.F.-Z., N.D.J., and C.A. All authors have read and agreed to the published version of the manuscript.

Funding: The research was conducted in the framework of the project ASHES and funded by the German Federal Ministry of Education and Research (BMBF, grand number 031A288). C.V. thanks the German Research Foundation (VO 1794/4-1) for financial support.

Acknowledgments: We appreciate the help of Marlene Müller, Edelgard Schölgens and Lucy Harrison. The authors also wish to thank Christopher DeLong, Steven Dean Calahan, and Sarah Kenyon for critically reading and editing the manuscript.

Conflicts of Interest: The authors declare no conflict of interest.

\section{Appendix A}

Table A1. Weights of materials in $\mathrm{g}$ for thermochemical post-treatment.

\begin{tabular}{cccccc}
\hline & GR & ASH & Chicken Manure & $\mathbf{N a}_{\mathbf{2}} \mathbf{S O}_{\mathbf{4}}$ & $\mathbf{K}_{\mathbf{2}} \mathbf{S O}_{\mathbf{4}}$ \\
\hline $\mathrm{GR}+\mathrm{Na}$ & 300 & 0 & 0 & 75 & 0 \\
$\mathrm{GR}+\mathrm{Na} / \mathrm{K}$ & 300 & 0 & 0 & 60 & 25 \\
$\mathrm{ASH}+\mathrm{Na}$ & 0 & 300 & 90 & 135 & 0 \\
$\mathrm{ASH}+\mathrm{Na} / \mathrm{K}$ & 0 & 300 & 90 & 110 & 45 \\
\hline
\end{tabular}




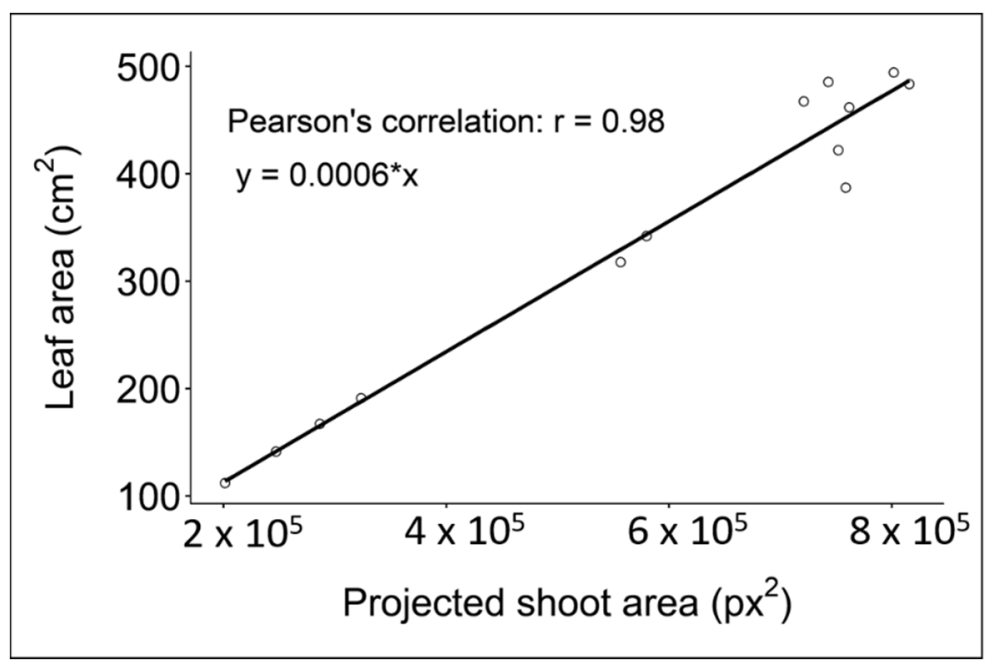

Figure A1. Correlation of projected shoot area measured in the "ScreenHouse" platform and true leaf areas measured after the harvest (Li-3100, Li-cor, Lincoln, NE, USA). Only projected shoot areas and true leaf areas of soybeans that fit in the "ScreenHouse" platform $40 \mathrm{~d}$ after transplanting, i.e., 13 plants were correlated to calculate the calibration curve for transformation the data from $\mathrm{px}^{2}$ to $\mathrm{cm}^{2}$.

Appendix A.1. Description of Phases Which Contain No P

\section{Appendix A.1.1. GR-Based Fertilizers}

GR was produced by gasification at $827^{\circ} \mathrm{C}$ in a reducing atmosphere. However, gasification was an incomplete thermal conversion, indicated also by LOI $36 \mathrm{wt} . \%$ (Table 1). Therefore, phases could be detected which are not normally stable at $827^{\circ} \mathrm{C}$. For example, $\mathrm{KCl}$ "labelled as $\mathrm{Cl}^{\prime}$ " has a melting point below $800{ }^{\circ} \mathrm{C}$ [66] and was still present in the sample. The presence of $\mathrm{KCl}$ and $\mathrm{CaCO}_{3}$ " $\mathrm{C}^{\text {" }}$ are in agreement with the analysis of biochar (gasification at $500^{\circ} \mathrm{C}$ ) of chicken manure by Bergfeldt et al. [18]. Apparently, the formation of both phases is not influenced by co-gasification with bagasse. Only $\mathrm{SiO}_{2}$ as quartz " $\mathrm{Q}$ " could be detected (Figure A2 and Table A2).

The thermochemical post-treatment with alkali additives at $1000{ }^{\circ} \mathrm{C}$ in a reducing atmosphere reduced the LOI to below $10 \%$ and transformed the crystalline phases. Magnetite " $\mathrm{M}$ " identified in gasification residue was oxidized to hematite " $\mathrm{H}$ " because samples were cooled down in air (Figure A2, Table A2). The use of sodium and potassium sulfates as additives supports the formation of anhydrate $\left(\mathrm{CaSO}_{4}\right)$ " $\mathrm{An}$ ". $\mathrm{SiO}_{2}$ reacts on the one hand with $\mathrm{CaCO}_{3}$ and $\mathrm{Mg}$-phases to Akermanite $\left(\mathrm{Ca}_{2} \mathrm{MgSi}_{2} \mathrm{O}_{7}\right)$ " $\mathrm{A}$ " and on the other hand, it reacts with additives $\mathrm{Na}_{2} \mathrm{SO}_{4}$ und $\mathrm{K}_{2} \mathrm{SO}_{4}$ to form phases according to the nepheline-group $\left((\mathrm{Na}, \mathrm{K}) \mathrm{AlSiO}_{4}\right)$ “ $\mathrm{E}$ ”. Additionally, the $\mathrm{K}$-endmember Kalsilite $\left(\mathrm{KAlSiO}_{4}\right)$ ' $\mathrm{K}$ ' was detected, in case $\mathrm{K}_{2} \mathrm{SO}_{4}$ was an additive in $\mathrm{GR}+\mathrm{Na} / \mathrm{K}$.

\section{Appendix A.1.2. ASH-Based Fertilizers}

ASH contains the same main phases as in GR. These are quartz " $Q$ " and calcite " $\mathrm{C}$ ". Additionally, they contain free lime " $\mathrm{F}$ ", periclase $\mathrm{MgO}$ " $\mathrm{G}$ ", hematite " $\mathrm{H}$ " and further silicate phases Albite $(\mathrm{Na}, \mathrm{Ca})(\mathrm{Si}, \mathrm{Al})_{4} \mathrm{O}_{8}{ }^{\prime} \mathrm{T}^{\prime}, \mathrm{NaAlSi}_{2} \mathrm{O}_{6}{ }^{\prime} \mathrm{U}^{\prime}$, and Leucite $\mathrm{KAlSi}_{2} \mathrm{O}_{6}{ }^{\prime} \mathrm{V}^{\prime}$ (Figure A6, Table A2). The thermochemical post-treatment with alkali sulfates leads to the transformation of two silicate phases Akermanite " $\mathrm{A}$ " and $\mathrm{Ca}_{4} \mathrm{Na}_{4} \mathrm{Si}_{6} \mathrm{O}_{18}$ " $\mathrm{B}$ " (Figure $\mathrm{A} 6$ and Table A2). One alkali sulfate phase was formed by additive excess. This is $\mathrm{NaKSO}_{4}$ in sample $\mathrm{Ash}+\mathrm{Na}$ and $\mathrm{K}_{3} \mathrm{Na}\left(\mathrm{SO}_{4}\right)_{2}$ in sample $\mathrm{Ash}+\mathrm{Na} / \mathrm{K}$ (Table A2). 


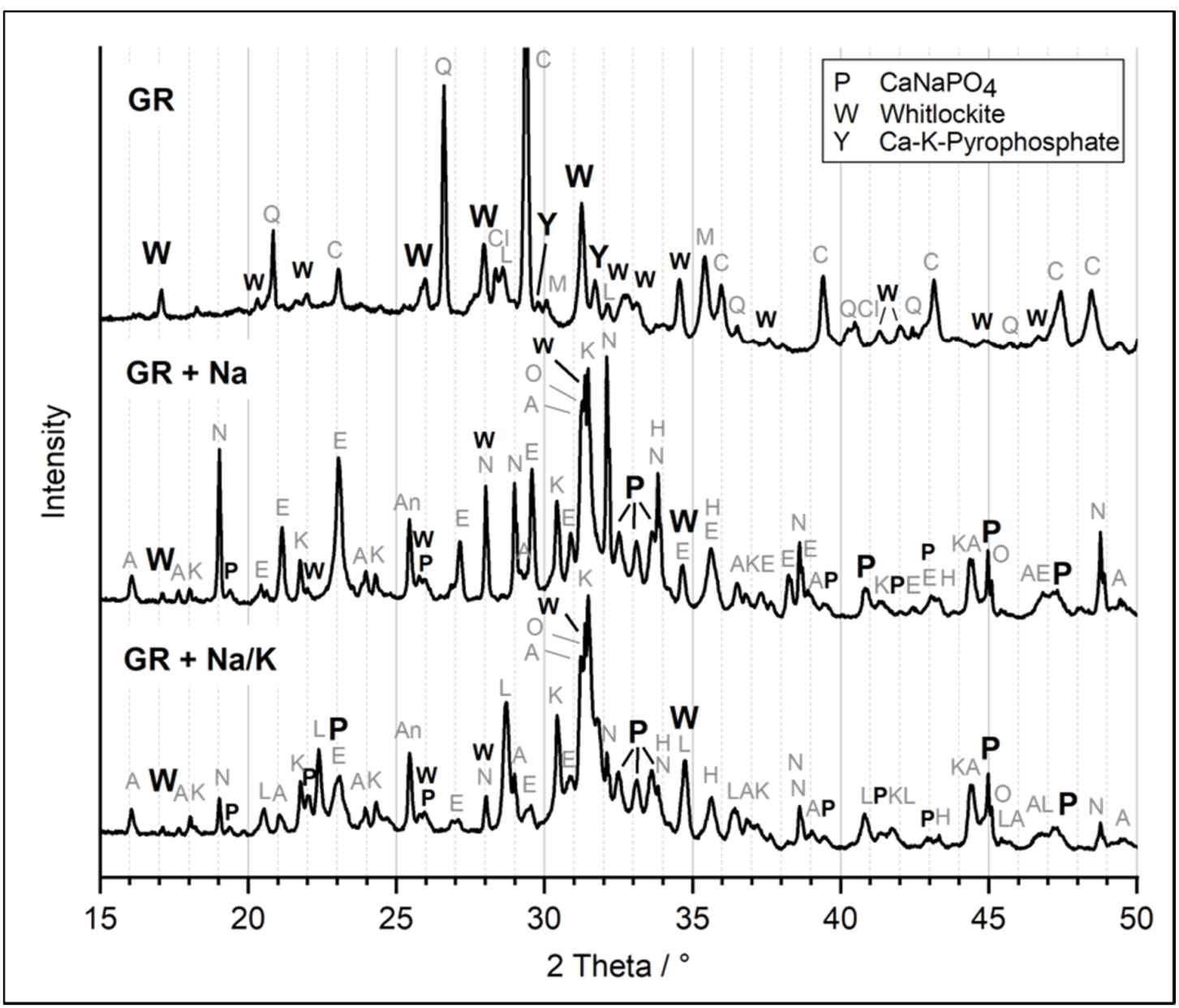

Figure A2. Diffraction pattern for GR and its thermochemical treated products with $\mathrm{Na}_{2} \mathrm{SO}_{4}(\mathrm{GR}+\mathrm{Na})$ and $\mathrm{Na}_{2} \mathrm{SO}_{4} / \mathrm{K}_{2} \mathrm{SO}_{4}(\mathrm{GR}+\mathrm{Na} / \mathrm{K})$. Phosphate phases (bold): $\mathrm{P}-\mathrm{CaNaPO}_{4}, \mathrm{~W}-$ Whitlockite type, $\mathrm{Y}-\mathrm{CaK}_{2} \mathrm{P}_{2} \mathrm{O}_{7}$; Other phases: A-Akermanite $\mathrm{Ca}_{2} \mathrm{MgSi}_{2} \mathrm{O}_{7}, \mathrm{An}$-Anhydrate $\mathrm{CaSO}_{4}, \mathrm{C}-$ Calcite

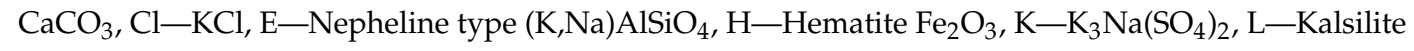
$\mathrm{KAlSiO}_{4}$ (a Nepheline type), $\mathrm{M}-$ Magnetite $\mathrm{Fe}_{3} \mathrm{O}_{4}, \mathrm{~N}-\mathrm{Na}_{2} \mathrm{SO}_{4}, \mathrm{Q}-\mathrm{Quartz} \mathrm{SiO}_{2}$. 
Table A2. Identified mineral phases for GR-based and ASH-based fertilizers according to diffraction data. Meaning of symbols: '-' not present $\bigcirc$ low $\bigcirc$ medium high amount. This quantification is a crude semi-quantification with comparison of reflex intensity and chemical composition.

\begin{tabular}{|c|c|c|c|c|c|c|c|c|c|c|c|}
\hline & $\begin{array}{c}\text { Quartz } \\
\mathrm{SiO}_{2} \\
\mathrm{Q}\end{array}$ & $\begin{array}{c}\text { Sylvin } \mathrm{KCl} \\
\mathrm{Cl}\end{array}$ & $\begin{array}{c}\text { Calcite } \\
\mathrm{CaCO}_{3} \\
\mathrm{C}\end{array}$ & $\begin{array}{c}\text { Akermanite } \\
\mathrm{Ca}_{2} \mathrm{MgSi}_{2} \mathrm{O}_{7} \\
\mathrm{~A}\end{array}$ & $\begin{array}{l}\text { Nepheline } \\
(\mathrm{K}, \mathrm{Na}) \mathrm{AlSiO}_{4} \\
\text { E }\end{array}$ & $\begin{array}{c}\text { Kalsilite } \\
\mathrm{KAlSiO}_{4} \\
\mathrm{~L}\end{array}$ & $\begin{array}{c}\mathrm{Na}_{2} \mathrm{SO}_{4} \\
\mathrm{~N}\end{array}$ & $\begin{array}{c}\mathrm{K}_{3} \mathrm{Na}\left(\mathrm{SO}_{4}\right)_{2} \\
\mathrm{~K}\end{array}$ & $\begin{array}{c}\text { Anhydrate } \\
\mathrm{CaSO}_{4} \\
\mathrm{An}\end{array}$ & $\begin{array}{c}\text { Magnetite } \\
\mathrm{Fe}_{3} \mathrm{O}_{4} \\
\mathrm{M}\end{array}$ & $\begin{array}{c}\text { Hematite } \\
\mathrm{Fe}_{2} \mathrm{O}_{3} \\
\mathrm{H}\end{array}$ \\
\hline GR & 0 & 0 & 0 & - & - & - & - & - & - & 0 & - \\
\hline $\mathrm{GR}+\mathrm{Na}$ & - & - & - & & & - & & 0 & & - & \\
\hline \multirow[t]{2}{*}{$\mathrm{GR}+\mathrm{Na} / \mathrm{K}$} & - & - & - & & 0 & & & & & - & \\
\hline & $\begin{array}{c}\text { Quartz } \\
\mathrm{SiO}_{2} \\
\mathrm{Q}\end{array}$ & $\begin{array}{c}\text { Cristob. } \\
\mathrm{SiO}_{2} \\
\mathrm{Cr}\end{array}$ & $\begin{array}{c}\text { Calcite } \\
\mathrm{CaCO}_{3} \\
\mathrm{C}\end{array}$ & $\begin{array}{c}\text { Akermanite } \\
\mathrm{Ca}_{2} \mathrm{MgSi}_{2} \mathrm{O}_{7} \\
\mathrm{~A}\end{array}$ & $\begin{array}{c}\text { Free lime } \\
\mathrm{Ca}(\mathrm{OH})_{2} \\
\mathrm{~F}\end{array}$ & $\begin{array}{c}\mathrm{Na}_{4} \mathrm{Ca}_{4} \mathrm{Si}_{6} \mathrm{O}_{18} \\
\text { B }\end{array}$ & $\begin{array}{c}\mathrm{KNaSO}_{4} \\
\mathrm{~J}\end{array}$ & $\begin{array}{c}\mathrm{K}_{3} \mathrm{Na}\left(\mathrm{SO}_{4}\right)_{2} \\
\mathrm{~K}\end{array}$ & $\begin{array}{c}\text { Periclase } \\
\mathrm{MgO} \\
\mathrm{G}\end{array}$ & $\begin{array}{c}\text { Further } \\
\text { silicates } \\
\mathrm{T} / \mathrm{U} / \mathrm{V}\end{array}$ & $\begin{array}{c}\text { Hematite } \\
\mathrm{Fe}_{2} \mathrm{O}_{3} \\
\mathrm{H}\end{array}$ \\
\hline ASH & O & $O$ & 0 & $O$ & 0 & - & - & - & $O$ & 0 & $O$ \\
\hline $\mathrm{ASH}+\mathrm{Na}$ & - & - & - & & - & 0 & 0 & - & - & - & 0 \\
\hline $\begin{array}{c}\mathrm{ASH}+ \\
\mathrm{Na} / \mathrm{K}\end{array}$ & - & - & - & & - & 0 & - & 0 & - & - & 0 \\
\hline
\end{tabular}




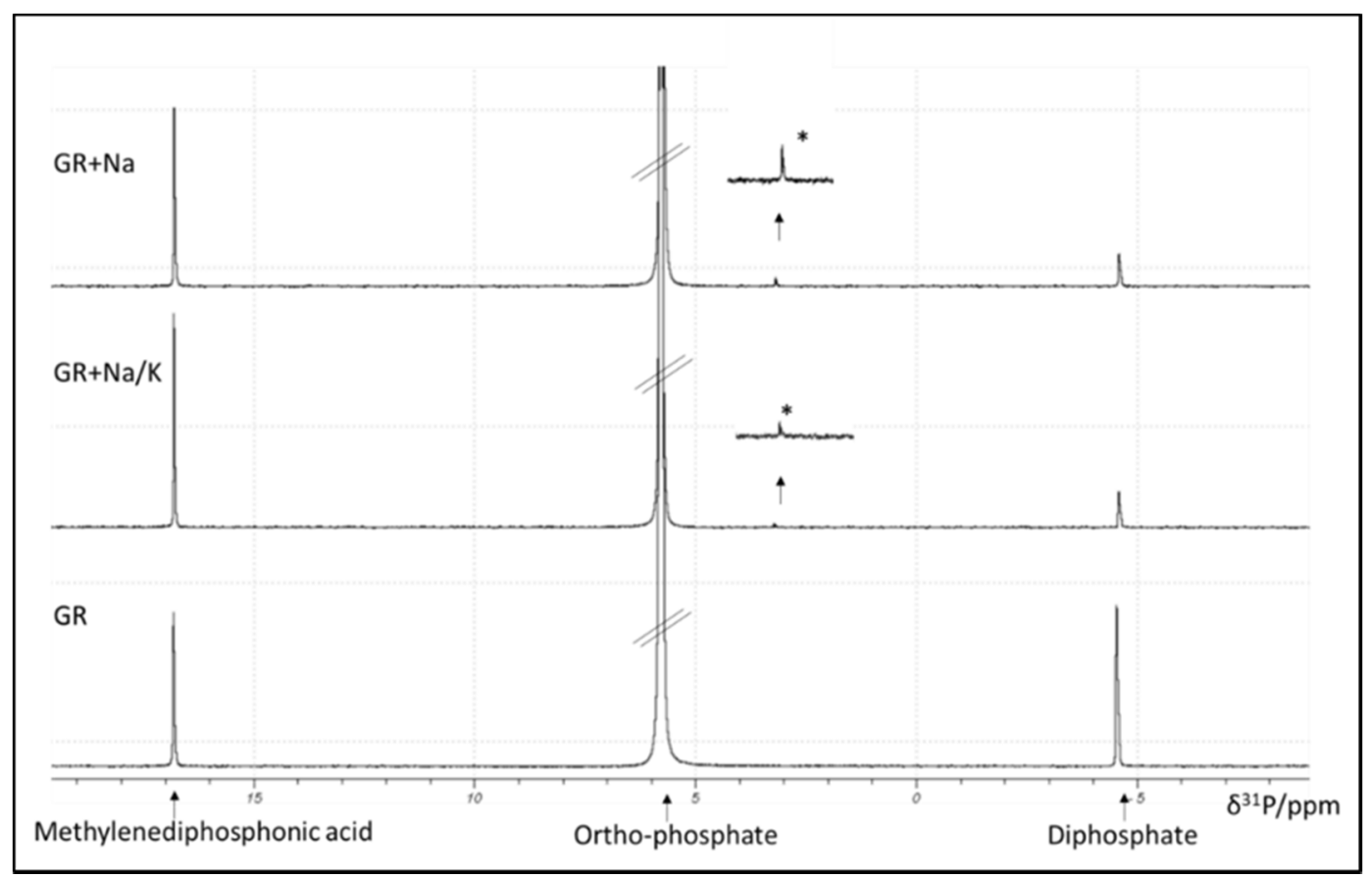

Figure A3. 1D ${ }^{31} \mathrm{P}$ NMR spectra and enlarged insets of GR, GR $+\mathrm{Na}$, and $\mathrm{GR}+\mathrm{Na} / \mathrm{K}$ recorded in a mixture of $30 \% \mathrm{NaOD}$ and $\mathrm{D}_{2} \mathrm{O}$ on a Bruker Avance III $600 \mathrm{MHz}$ with ${ }^{31} \mathrm{P}$ frequency of $242.81 \mathrm{MHz}$ ( $24 \mathrm{~K}$ scans, $\mathrm{aq}=0,67 \mathrm{~s} ; \mathrm{d} 1=1 \mathrm{~s}$ ). The spectra were referenced to methylenediphosphonic acid at 16.8 ppm. The signal marked with * is not assigned.

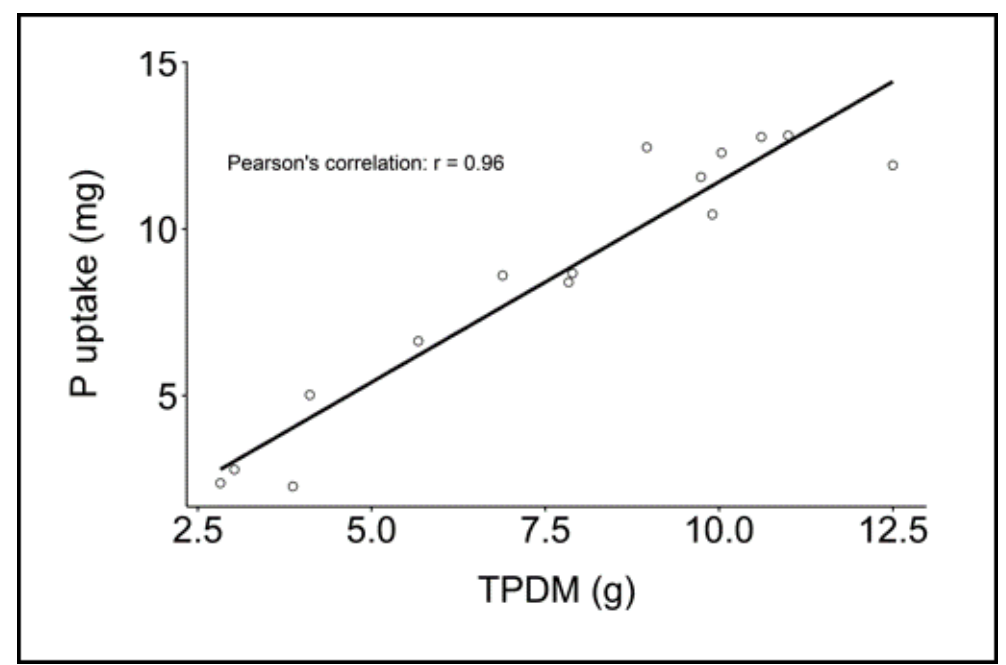

Figure A4. Correlation of TPDM and P uptake from GR, GR+Na, and GR+Na/K (first experiment).

Table A3. pH, aqua regia, Mehlich-I, and DGT harvest $_{\text {from the soils after harvest. DGT }}$ incubation of the fertilizers/Oxisol soil-mixture after 2 weeks incubation. The values represent means \pm standard deviations (duplicate measurements).

\begin{tabular}{cccccc}
\hline Used Fertilizer & $\mathbf{p H}$ & $\begin{array}{c}\text { Aqua Regia } \\
{[\mathbf{m g} / \mathbf{k g}]}\end{array}$ & $\begin{array}{c}\text { Mehlich-I } \\
{[\mathbf{m g} / \mathbf{k g}]}\end{array}$ & $\begin{array}{c}\text { DGT }_{\text {harvest }} \\
{[\boldsymbol{\mu g} / \mathbf{l}]}\end{array}$ & $\begin{array}{c}\text { DGT }_{\text {incubation }} \\
{[\boldsymbol{\mu} \mathbf{g} / \mathbf{l}]}\end{array}$ \\
\hline $\mathrm{No} \mathrm{P}$ & 5.4 & $447 \pm 3$ & $2.3 \pm 0.5$ & $2.5 \pm 2.1$ & $11.7 \pm 6.1$ \\
$\mathrm{GR}$ & 5.8 & $521 \pm 15$ & $8.1 \pm<0.1$ & $8.6 \pm 2.4$ & $19.0 \pm 4.2$ \\
$\mathrm{GR}+\mathrm{Na}$ & 5.7 & $530 \pm 7$ & $8.1 \pm 0.1$ & $19.4 \pm 7.8$ & $62.4 \pm 16.5$ \\
$\mathrm{GR}+\mathrm{Na} / \mathrm{K}$ & 5.7 & $529 \pm 39$ & $7.4 \pm 0.6$ & $13.2 \pm 7.3$ & $43.6 \pm 7.6$ \\
\hline
\end{tabular}




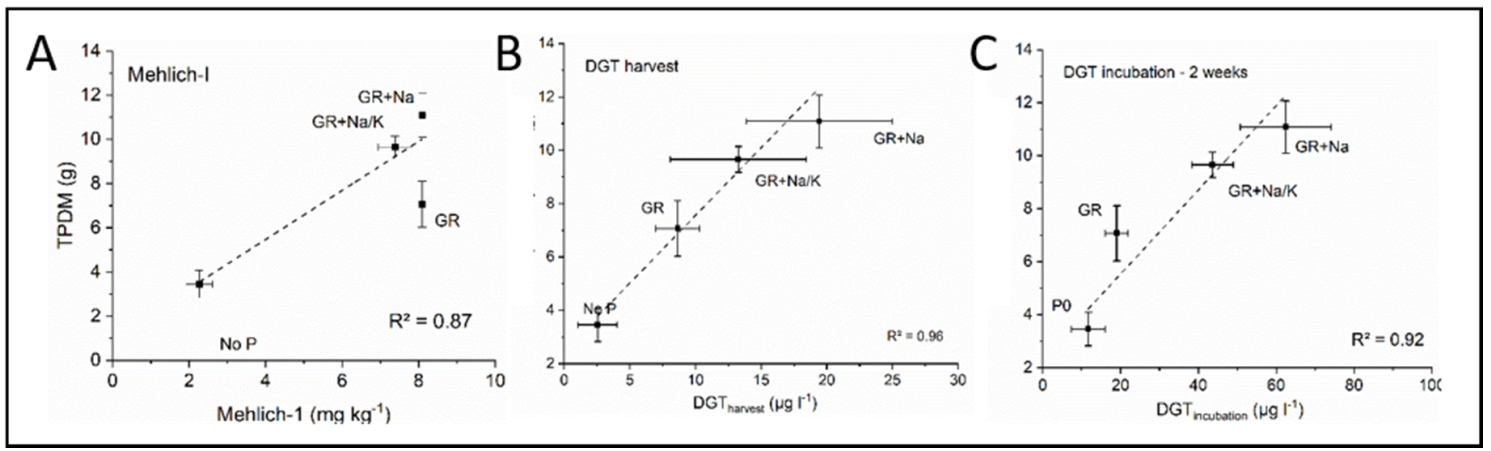

Figure A5. Linear correlation of TPDM vs. soil extraction methods Mehlich-I (A), DGT harvest (B), and $\mathrm{DGT}_{\text {incubation }}(\mathrm{C})$. All values are means \pm standard error of means (TPDM: four biological replicates,

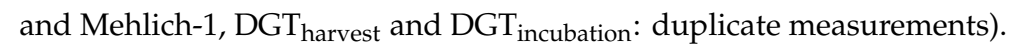

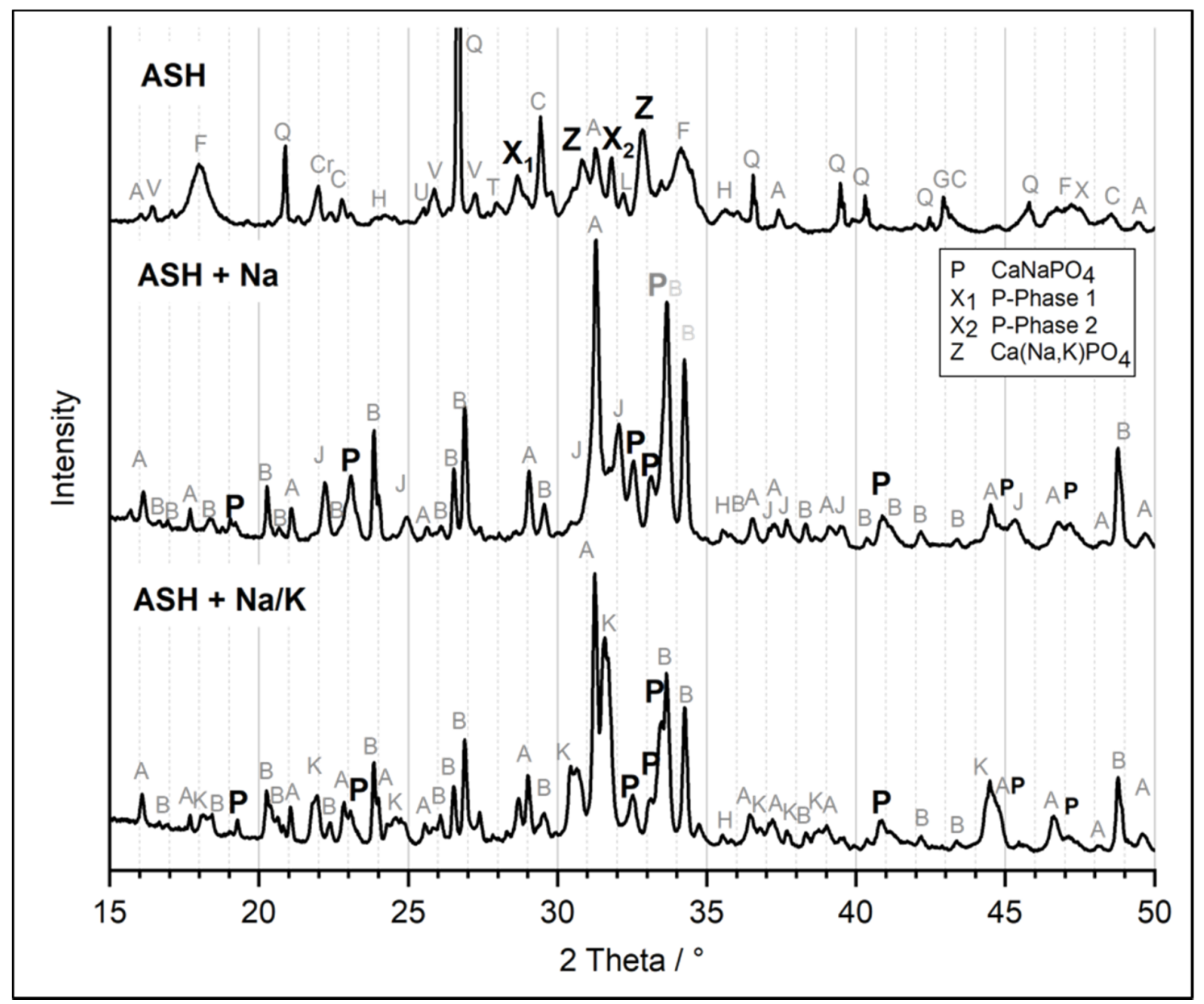

Figure A6. Diffraction pattern for ASH and its thermochemical treated products with $\mathrm{Na}_{2} \mathrm{SO}_{4}(\mathrm{ASH}+\mathrm{Na})$ and $\mathrm{Na}_{2} \mathrm{SO}_{4} / \mathrm{K}_{2} \mathrm{SO}_{4}(\mathrm{ASH}+\mathrm{Na} / \mathrm{K})$. Phosphate phases (bold): $\mathrm{P}-\mathrm{CaNaPO}_{4}, \mathrm{X}-\mathrm{CA}-/ \mathrm{FA}-$ soluble P-phase, $\mathrm{X}_{2}$-FA-soluble P-phase, $\mathrm{Z}-\mathrm{Ca}(\mathrm{Na}, \mathrm{K}) \mathrm{PO}_{4}$; Other phases: A-Akermanite $\mathrm{Ca}_{2} \mathrm{MgSi}_{2} \mathrm{O}_{7}$, $\mathrm{B}-\mathrm{Na}_{4} \mathrm{Ca}_{4} \mathrm{Si}_{6} \mathrm{O}_{18} ; \mathrm{C}$-Calcite $\mathrm{CaCO}_{3}, \mathrm{Cr}$-Cristobalite $\mathrm{SiO}_{2}, \mathrm{~F}$-free lime $\mathrm{Ca}(\mathrm{OH})_{2}, \mathrm{G}-\mathrm{MgO}$, $\mathrm{H}$-Hematite $\mathrm{Fe}_{2} \mathrm{O}_{3}, \mathrm{~J}-\mathrm{KNaSO}_{4}, \mathrm{~K}-\mathrm{K}_{3} \mathrm{Na}\left(\mathrm{SO}_{4}\right)_{2}, \mathrm{Q}$-Quartz $\mathrm{SiO}_{2}$, T-Albite $(\mathrm{Na}, \mathrm{Ca})(\mathrm{Si}, \mathrm{Al})_{4} \mathrm{O}_{8}$, $\mathrm{U}-\mathrm{NaAlSi}_{2} \mathrm{O}_{6}, \mathrm{~V}$-Leucite $\mathrm{KAlSi}_{2} \mathrm{O}_{6}$. 


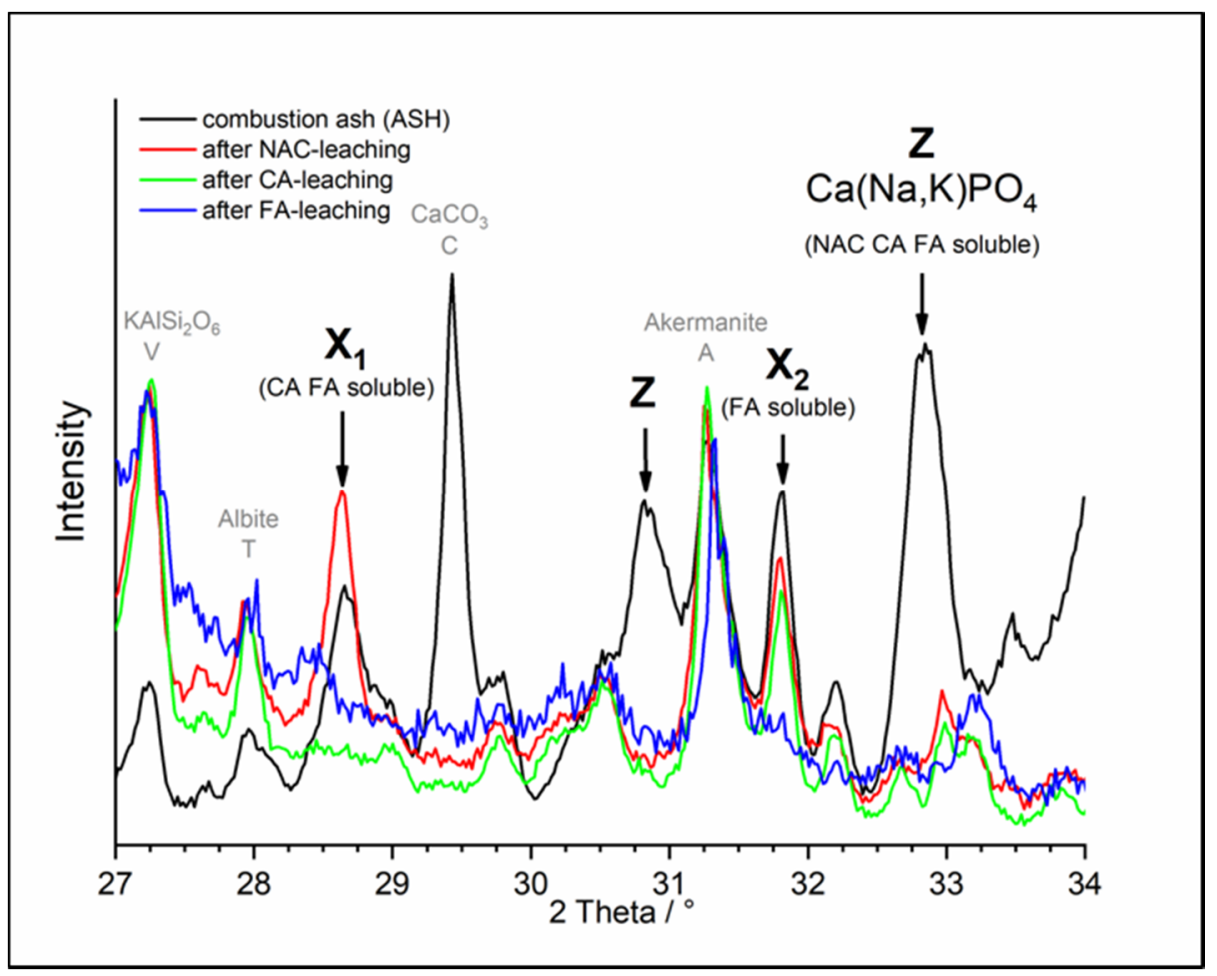

Figure A7. Section of diffraction pattern for original material ASH (black), leached after NAC (red), after CA (green), and after FA (blue).

\section{References}

1. Almazan, O.; Gonzalez, L.; Galvez, L. The sugar cane, its by-products and co-products. In Proceedings of the AMAS, Réduit, Mauritius, 17-18 November 1998; pp. 13-25.

2. Rocha, G.J.d.M.; Nascimento, V.M.; Gonçalves, A.R.; Silva, V.F.N.; Martín, C. Influence of mixed sugarcane bagasse samples evaluated by elemental and physical-chemical composition. Ind. Crops Prod. 2015, 64, 52-58. [CrossRef]

3. Ochoa George, P.A.; Eras, J.J.C.; Gutierrez, A.S.; Hens, L.; Vandecasteele, C. Residue from Sugarcane Juice Filtration (Filter Cake): Energy Use at the Sugar Factory. Waste Biomass Valorization 2010, 1, 407-413. [CrossRef]

4. FAOSTAT. Available online: http://www.fao.org/faostat/en/\#compare (accessed on 3 March 2020).

5. Ferreira, E.P.d.B.; Fageriae, N.K.; Didonet, A.D. Chemical properties of an oxisol under organic management as influenced by application of sugarcane bagasse ash. Revista Ciência Agronômica 2012, 43, 228-236. [CrossRef]

6. Pita, V.; Vasconcelos, E.; Cabral, F.; Ribeiro, H.M. Effect of ash from sugarcane bagasse and wood co-combustion on corn growth and soil properties. Arch. Agron. Soil Sci. 2012, 58, S206-S212. [CrossRef]

7. Thind, H.S.; Singh, Y.; Sharma, S.; Singh, V.; Sran, H.S.; Singh, B. Phosphorus fertilizing potential of bagasse ash and rice husk ash in wheat-rice system on alkaline loamy sand soil. J. Agric. Sci. 2017, 155, 465-474. [CrossRef]

8. Gonfa, A.; Bedadi, B.; Argaw, A. Effect of bagasse ash and filter cake amendments on wheat (Triticum turgidum L.var. durum) yield and yield components in nitisol. Int. J. Recycl. Org. Waste Agric. 2018, 7, 231-240. [CrossRef]

9. Li, X.; Rubæk, G.H.; Sørensen, P. Availability of potassium in biomass combustion ashes and gasification biochars after application to soils with variable $\mathrm{pH}$ and clay content. Arch. Agron. Soil Sci. 2017, 64, 1119-1130. [CrossRef]

10. Tran, Q.T.; Maeda, M.; Oshita, K.; Takaoka, M.; Saito, K. Phosphorus and potassium availability from cattle manure ash in relation to their extractability and grass tetany hazard. Soil Sci. Plant Nutr. 2018, 64, 415-422. [CrossRef] 
11. Demeyer, A.; Voundi Nkana, J.C.; Verloo, M.G. Characteristics of wood ash and influence on soil properties and nutrient uptake: An overview. Bioresour. Technol. 2001, 77, 287-295. [CrossRef]

12. Freire, M.; Lopes, H.; Tarelho, L.A.C. Critical aspects of biomass ashes utilization in soils: Composition, leachability, PAH and PCDD/F. Waste Manag. 2015, 46, 304-315. [CrossRef]

13. Schiemenz, K.; Eichler-Löbermann, B. Biomass ashes and their phosphorus fertilizing effect on different crops. Nutr. Cycl. Agroecosyst. 2010, 87, 471-482. [CrossRef]

14. Müller-Stöver, D.S.; Jakobsen, I.; Grønlund, M.; Rolsted, M.M.M.; Magid, J.; Hauggaard-Nielsen, H.; Goss, M. Phosphorus bioavailability in ash from straw and sewage sludge processed by low-temperature biomass gasification. Soil Use Manag. 2018, 34, 9-17. [CrossRef]

15. Basso, C.J.; Muraro, D.S.; Girotto, E.; Silva, D.R.O.d.; Silva, A.N.d. Poultry litter and swine compost as nutrients sources in millet. Biosci. J. 2017, 288-296. [CrossRef]

16. Abdala, D.B.; Ghosh, A.K.; da Silva, I.R.; de Novais, R.F.; Alvarez Venegas, V.H. Phosphorus saturation of a tropical soil and related P leaching caused by poultry litter addition. Agric. Ecosyst. Environ. 2012, 162, 15-23. [CrossRef]

17. Christel, W.; Bruun, S.; Magid, J.; Jensen, L.S. Phosphorus availability from the solid fraction of pig slurry is altered by composting or thermal treatment. Bioresour. Technol. 2014, 169, 543-551. [CrossRef]

18. Bergfeldt, B.; Tomasi Morgano, M.; Leibold, H.; Richter, F.; Stapf, D. Recovery of Phosphorus and other Nutrients during Pyrolysis of Chicken Manure. Agriculture 2018, 8, 187. [CrossRef]

19. Kratz, S.; Vogel, C.; Adam, C. Agronomic performance of P recycling fertilizers and methods to predict it: A review. Nutr. Cycl. Agroecosyst. 2019, 115, 1-39. [CrossRef]

20. Severin, M.; Breuer, J.; Rex, M.; Stemann, J.; Adam, C.; Van den Weghe, H.; Kücke, M. Phosphate fertiliser value of heat treated sewage sludge ash. Plant Soil Environ. 2014, 60, 555-561. [CrossRef]

21. Steckenmesser, D.; Vogel, C.; Adam, C.; Steffens, D. Effect of various types of thermochemical processing of sewage sludges on phosphorus speciation, solubility, and fertilization performance. Waste Manag. 2017, 62, 194-203. [CrossRef]

22. Vogel, C.; Rivard, C.; Wilken, V.; Muskolus, A.; Adam, C. Performance of secondary P-fertilizers in pot experiments analyzed by phosphorus X-ray absorption near-edge structure (XANES) spectroscopy. Ambio 2018, 47, 62-72. [CrossRef]

23. Herzel, H.; Krüger, O.; Hermann, L.; Adam, C. Sewage sludge ash-A promising secondary phosphorus source for fertilizer production. Sci. Total Environ. 2016, 542, 1136-1143. [CrossRef]

24. Brod, E.; Øgaard, A.F.; Haraldsen, T.K.; Krogstad, T. Waste products as alternative phosphorus fertilisers part II: Predicting P fertilisation effects by chemical extraction. Nutr. Cycl. Agroecosys. 2015, 103, 187-199. [CrossRef]

25. Empresa Brasileira de Pesquisa Agropecuária (EMBRAPA). Manual for Methods of Soil Analysis, 2nd ed.; National Service for Soil Survey and Soil Conservation: Rio de Janeiro, Brazil, 1997.

26. Six, L.; Smolders, E.; Merckx, R. The performance of DGT versus conventional soil phosphorus tests in tropical soils-Maize and rice responses to P application. Plant Soil 2013, 366, 49-66. [CrossRef]

27. Six, L.; Smolders, E.; Merckx, R. Testing phosphorus availability for maize with DGT in weathered soils amended with organic materials. Plant Soil 2014, 376, 177-192. [CrossRef]

28. Hartmann, T.E.; Wollmann, I.; You, Y.; Müller, T. Sensitivity of Three Phosphate Extraction Methods to the Application of Phosphate Species Differing in Immediate Plant Availability. Agronomy 2019, 9, 29. [CrossRef]

29. Duboc, O.; Santner, J.; Golestani Fard, A.; Zehetner, F.; Tacconi, J.; Wenzel, W.W. Predicting phosphorus availability from chemically diverse conventional and recycling fertilizers. Sci. Total Environ. 2017, 599-600, 1160-1170. [CrossRef]

30. Vogel, C.; Sekine, R.; Steckenmesser, D.; Lombi, E.; Steffens, D.; Adam, C. Phosphorus availability of sewage sludge-based fertilizers determined by the diffusive gradients in thin films (DGT) technique. J. Plant Nutr. Soil Sci. 2017, 180, 594-601. [CrossRef]

31. Nanzer, S.; Oberson, A.; Huthwelker, T.; Eggenberger, U.; Frossard, E. The Molecular Environment of Phosphorus in Sewage Sludge Ash: Implications for Bioavailability. J. Environ. Qual. 2014, 43, 1050-1060. [CrossRef]

32. Yusiharni, B.E.; Ziadi, H.; Gilkes, R.J. A laboratory and glasshouse evaluation of chicken litter ash, wood ash, and iron smelting slag as liming agents and P fertilisers. Soil Res. 2007, 45, 374-389. [CrossRef] 
33. Staroń, P.; Kowalski, Z.; Staroń, A.; Banach, M. Thermal treatment of waste from the meat industry in high scale rotary kiln. Int. J. Environ. Sci. Technol. 2017, 14, 1157-1168. [CrossRef]

34. Bogush, A.A.; Stegemann, J.A.; Williams, R.; Wood, I.G. Element speciation in UK biomass power plant residues based on composition, mineralogy, microstructure and leaching. Fuel 2018, 211, 712-725. [CrossRef]

35. Schettino, M.A.S.; Holanda, J.N.F. Characterization of Sugarcane Bagasse ash Waste for Its Use in Ceramic Floor Tile. Procedia Mater. Sci. 2015, 8, 190-196. [CrossRef]

36. Govindarajan, D.; Jayalakshmi, G. XRD, FTIR and Microstructure Studies of Calcined Sugarcane Bagasse Ash. Adv. Appl. Sci. Res. 2011, 2, 544-549.

37. Stemann, J.; Peplinski, B.; Adam, C. Thermochemical treatment of sewage sludge ash with sodium salt additives for phosphorus fertilizer production-Analysis of underlying chemical reactions. Waste Manag. 2015, 45, 385-390. [CrossRef] [PubMed]

38. Kuepper, B.; Steinweg, T.; Piotrowski, M. Feed and Livestock in Brazil, China, EU Consume Most Cerrado Soy. Available online: www.chainreactionresearch.com (accessed on 6 March 2020).

39. Bordonal, R.d.O.; Carvalho, J.L.N.; Lal, R.; de Figueiredo, E.B.; de Oliveira, B.G.; La Scala, N. Sustainability of sugarcane production in Brazil. A review. Agron. Sustain. Dev. 2018, 38, 13. [CrossRef]

40. Withers, P.J.A.; Rodrigues, M.; Soltangheisi, A.; de Carvalho, T.S.; Guilherme, L.R.G.; Benites, V.d.M.; Gatiboni, L.C.; de Sousa, D.M.G.; Nunes, R.d.S.; Rosolem, C.A.; et al. Transitions to sustainable management of phosphorus in Brazilian agriculture. Sci. Rep. 2018, 8, 2537. [CrossRef]

41. Vodegel, S.; Müller, F. BioÖkonomie International: ASHES—Rückführung von Nährstoffen aus Aschen von Thermo-Chemischen Prozessen mit Bagasse bzw. Bagassestroh, Teilprojekt C.; CUTEC: Clausthal-Zellerfeld, Germany, 2019.

42. Pettersson, A.; Åmand, L.-E.; Steenari, B.-M. Leaching of ashes from co-combustion of sewage sludge and wood-Part I: Recovery of phosphorus. Biomass Bioenergy 2008, 32, 224-235. [CrossRef]

43. Pan, H.; Eberhardt, T. Characterization of fly ash from the gasification of wood and assessment for its application as a soil amendment. Bioresources 2011, 6. [CrossRef]

44. FAO. Fertilizer Use by Crop in Brazil; Food and Agriculture Organization of the United Nation: Rome, Italiy, 2004.

45. Nabel, M.; Schrey, S.D.; Poorter, H.; Koller, R.; Nagel, K.A.; Temperton, V.M.; Dietrich, C.C.; Briese, C.; Jablonowski, N.D. Coming Late for Dinner: Localized Digestate Depot Fertilization for Extensive Cultivation of Marginal Soil With Sida hermaphrodita. Front. Plant Sci. 2018, 9, 1095. [CrossRef]

46. Nakhforoosh, A.; Bodewein, T.; Fiorani, F.; Bodner, G. Identification of Water Use Strategies at Early Growth Stages in Durum Wheat from Shoot Phenotyping and Physiological Measurements. Front. Plant Sci. 2016, 7. [CrossRef]

47. Scharr, H.; Briese, C.; Embgenbroich, P.; Fischbach, A.; Fiorani, F.; Müller-Linow, M. Fast High Resolution Volume Carving for 3D Plant Shoot Reconstruction. Front. Plant Sci. 2017, 8, 1680. [CrossRef] [PubMed]

48. Gutiérrez-boem, F.H.; Thomas, G.W. Phosphorus nutrition and water deficits in field-grown soybeans. Plant Soil 1999, 207, 87-96. [CrossRef]

49. DIN EN 16174. Schlamm, behandelter Bioabfall und Boden-Aufschluss von mit Königswasser löslichen Anteilen von Elementen. Deutsches Institut für Normung 2012. [CrossRef]

50. Mehlich, A. Determination of P, Ca, Mg, K, Na, and NH4. Soil Test. Div. 1953, 1-53, $23-89$.

51. EU. Regulation (EC) No 2003/2003 of the European Parliament and of the Council of 13 October 2003 Relating to Fertilizers; L304, O.J.o.t.E.U., Ed.; EU: Brussels, Belgium, 2003.

52. Vestergren, J.; Vincent, A.G.; Jansson, M.; Persson, P.; Ilstedt, U.; Gröbner, G.; Giesler, R.; Schleucher, J. High-Resolution Characterization of Organic Phosphorus in Soil Extracts Using 2D 1H-31P NMR Correlation Spectroscopy. Environ. Sci. Technol. 2012, 46, 3950-3956. [CrossRef]

53. Cade-Menun, B.; Liu, C.W. Solution Phosphorus-31 Nuclear Magnetic Resonance Spectroscopy of Soils from 2005 to 2013: A Review of Sample Preparation and Experimental Parameters. Soil Sci. Soc. Am. J. 2014, 78, 19-37. [CrossRef]

54. Ando, J.; Matsuno, S. $\mathrm{Ca}_{3}\left(\mathrm{PO}_{4}\right)_{2}-\mathrm{CaNaPO}_{4}$ System. B Chem. Soc. Jpn. 1968, 41, 342-347. [CrossRef]

55. Zogli, P.; Pingault, L.; Libault, M. Physiological and Molecular Mechanisms and Adaptation Strategies in Soybean (Glycine max) Under Phosphate Deficiency. In Legume Nitrogen Fixation in Soils with Low Phosphorus Availability: Adaptation and Regulatory Implication; Sulieman, S., Tran, L.-S.P., Eds.; Springer International Publishing: Cham, Switzerland, 2017; pp. 219-242. [CrossRef] 
56. Lopez, R.; Padilla, E.; Bachmann, S.; Eichler-Löbermann, B. Effects of biomass ashes on plant nutrition in tropical and temperate regions. J. Agric. Rural Dev. Trop. Subtrop. 2009, 110, 49-58.

57. Akkajit, P.; DeSutter, T.; Tongcumpou, C. Short-term effects of sugarcane waste products from ethanol production plant as soil amendments on sugarcane growth and metal stabilization. Environ. Sci. Process. Impacts 2013, 15, 947-954. [CrossRef]

58. Webber, C.L., III; White, P.M., Jr.; Spaunhorst, D.J.; Petrie, E.C. Impact of Sugarcane Bagasse Ash as an Amendment on the Physical Properties, Nutrient Content and Seedling Growth of a Certified Organic Greenhouse Growing Media. J. Agric. Sci. 2017, 9, 1. [CrossRef]

59. Camps-Arbestain, M.; Shen, Q.; Wang, T.; van Twieten, L.; Novak, J. Available nutrients in biochar. In Biochar: A Guide to Analytical Methods; Singh, B., Camps-Arbestain, M., Lehmann, J., Eds.; CSIRO Publishing: Clayton, VIC, Australia, 2017; pp. 109-125.

60. Gunawardane, R.P.; Glasser, F.P. Reaction of chlorapatite, $\mathrm{Ca}_{5}\left(\mathrm{PO}_{4}\right)_{3}(\mathrm{Cl}, \mathrm{F})$ with sodium carbonate and silica. J. Mater. Sci. 1979, 14, 2797-2810. [CrossRef]

61. Vance, C.P.; Uhde-Stone, C.; Allan, D.L. Phosphorus acquisition and use: Critical adaptations by plants for securing a nonrenewable resource. New Phytol. 2003, 157, 423-447. [CrossRef]

62. Tawaraya, K.; Horie, R.; Shinano, T.; Wagatsuma, T.; Saito, K.; Oikawa, A. Metabolite profiling of soybean root exudates under phosphorus deficiency. Soil Sci. Plant Nutr. 2014, 60, 679-694. [CrossRef]

63. Haynes, R.J. Soil acidification induced by leguminous crops. Grass Forage Sci. 1983, 38, 1-11. [CrossRef]

64. Hinsinger, P.; Plassard, C.; Tang, C.; Jaillard, B. Origins of root-mediated pH changes in the rhizosphere and their responses to environmental constraints: A review. Plant Soil 2003, 248, 43-59. [CrossRef]

65. Hinsinger, P.; Herrmann, L.; Lesueur, D.; Robin, A.; Trap, J.; Waithaisong, K.; Plassard, C. Impact of roots, microorganisms and microfauna on the fate of soil phosphorus in the rhizosphere. In Annual Plant Reviews Volume 48; Plaxton, W.C., Lambers, H., Eds.; John Wiley \& Sons, Ltd.: Hoboken, NJ, USA, 2015; pp. $375-407$. [CrossRef]

66. Rowe, J.J.; Morey, G.W.; Zen, C.S. The Quinary Reciprocal Salt System $\mathrm{Na}, \mathrm{K}, \mathrm{Mg}, \mathrm{Ca} / \mathrm{Cl}, \mathrm{SO}_{4}-\mathrm{A}$ Review of the Literature with New Data; U.S. Government Printing Office Washington: Washington, DC, USA, 1972. 